\title{
The construction of occupational professionalism among business rescue practitioners supplying professional bodies.
}

\author{
Onesmus Ayaya \\ Marius Pretorius \\ Department of Business Management \\ University of Pretoria
}

Key word

business, construction, framework, practitioner, professionalism, rescue

\begin{abstract}
Purpose of the research: To identify and explore the construction of professionalism in a multiple professional bodies (MPB) landscape in South Africa (SA) and demonstrate how such construction can be used to enhance professional accreditation regime.

Design of research and methodology: The study used a qualitative research design. This required five consecutive steps of (a) interviewing member services managers at four professional bodies (PBs); (b) systematic content analysis of codes of professional conduct (CPCs) and policy statements to identify constituent professionalism notions; (c) a systematic search of the literature to identify notions of professionalism mentioned in definitions and explanations of the construct; and (d) analysis of notions of professionalism using the constant comparison procedure to reveal key themes. The results in (a) through to (d) were used to advance a programmatic framework to construct professionalism in an MPB landscape.

Research results: The construction of professionalism is linked to services rendered and competencies in the MPB landscape. The existing licensing regime encapsulates the increased importance of the MPB landscape, leading to a shift away from a conventional conceptualisation of professionalism in a single professional body (PB) setting. A total of 90 separate notions of professionalism were identified in the 192 scholarly papers included in our study. The identified theme within BRP professionalism (emphasising relational aspects) point to practitioner dealings with (i) clients (business rescue candidates); (ii) government and others; (iii) the PB; and (iv) oneself to gain the essence of occupation. There is fragmentation between the constructed conceptualisations of professionalism among PBs, leading to an incoherent and inconsistent expert accreditation regime.

Practical implications and value: The findings of the study are useful in the integration of practitioner learning and development practices in the PBs whose members serve as BRPs. BRP is a regulated occupation and requires a distinct professional accreditation framework (PAF) to integrate multidimensional professionalism in the MPB landscape. Approaches to enhance accreditation should consider delineating BRP services and task from interview results from a community of practitioners. The PAF will structure the construction, investigation, and documentation of occupational professionalism required by the licensing authorities. It will also help delineate BRP as a discipline worth of academic and professional pursuits with known competencies.
\end{abstract}

\section{Introduction}

Professionalism is an important learning and development outcome in professional certification (Macheridis \& Paulsson, 2019). Evans (2011) argues that professional standards lead to a professionalism notion that focuses predominantly on practitioner behaviour instead of practitioner attitudes and intellectual capacity development. Sandberg and Pinnington (2009) equate professional competence with professionalism. Van De Camp, Vernooij-Dassen, Grol and Bottema (2004: 696) contend that professionalism is a multidimensional construct. There is no agreement on how to define professionalism (Arnold, 2002). Evetts (2003) analyses professionalism from a normative value system and ideological power occupation to motivate and facilitate occupation improvement. Evetts (2000: 397) considers professionalism an evolved practice construct from occupations that are based on technical and articulation knowledge. The Companies and Intellectual Property Commission (CIPC, 2020) issued 
continuing professional development (CPD) to enhance professionalism among practitioners from multiple professional bodies (MPBs).

\section{Background}

The constitution of the business rescue practitioner (BRP) occupation in South Africa (SA) occurred with the promulgation of the Companies Act (Act No. 71 of 2008, from now on the "Act"). The legal provisions in the Act took effect on 1 May 2011 and allowed practitioners from MPBs (Table 1) to provide turnaround services. Questions worth asking is: How is professionalism constructed in the MPB landscape like corporate turnaround management (BR)? What dimensions of professionalism would apply to the BRP or the BRP occupation in SA? These questions must be answered for the BRP occupation to improve towards intended practice goals.

The understanding of the construction of professionalism among the BRP-supplying professional bodies (PBs) is vital in the learning and development of BRPs. The demand for BRP services (Table 1) prompted a rethink of how BR needs can be met by professionals holding membership with PBs recognised by the South African Qualifications Authority (SAQA) and the CIPC. Table 1 shows the number of BRs since 2011. The volume of work on corporate turnaround has been growing. Table 2 shows a summary of BRPs registered from different PBs in compliance with the Act's requirements. As of 30 September 2020, the four PBs contribute $81 \%$ of the registered BRPs. These PBs are the South African Institute of Chartered Accountants (SAICA) (27\%), the South African Restructuring and Insolvency Practitioners Association (SARIPA) (22\%), the Law Society $(20 \%)$ and the Turnaround Management Association of South Africa (BRA-SA) (12\%). Table 2 further shows that $42 \%$ of the BRPs on the CIPC register were not linked to any of the listed PBs. In terms of the regulations, the unclassified BRPs must apply through the recognised PBs. This move supports the use of professionals in BR work, and by extension, professionalism should have a shared constructed meaning.

The members of the listed PBs did not train in BRP practices, and the construction of professionalism is bound to be different. Pretorius (2014) contend that BRP is an occupation that emanated from the promulgation of the Act. It was hoped that the emergence of a BRP profession would result from the implementation of the Act.

Table 1: Number of BRP companies and volume of work

\begin{tabular}{|l|l|l|l|l|l|l|l|l|l|}
\hline & \multicolumn{9}{|l}{ Years } \\
\hline Month & $2011-$ & $2012-$ & $2013-$ & $2014-$ & $2015-$ & $2016-$ & $2017-$ & Total & Mean \\
& 2012 & 2013 & 2014 & 2015 & 2016 & 2017 & 2018 & & \\
\hline April & 0 & 30 & 39 & 24 & 42 & 25 & 16 & 176 & 25 \\
\hline May & 5 & 45 & 50 & 39 & 33 & 40 & 27 & 239 & 34 \\
\hline June & 28 & 26 & 37 & 34 & 21 & 36 & 43 & 225 & 32 \\
\hline July & 25 & 23 & 47 & 43 & 67 & 40 & 23 & 268 & 38 \\
\hline August & 38 & 59 & 49 & 66 & 56 & 45 & 33 & 346 & 50 \\
\hline September & 81 & 55 & 26 & 42 & 34 & 29 & 41 & 308 & 44 \\
\hline October & 27 & 47 & 45 & 44 & 57 & 34 & 33 & 287 & 41 \\
\hline November & 42 & 56 & 28 & 34 & 55 & 32 & 47 & 294 & 42 \\
\hline December & 59 & 18 & 14 & 25 & 21 & 22 & 18 & 177 & 25 \\
\hline January & 67 & 14 & 35 & 31 & 22 & 23 & 25 & 217 & 31 \\
\hline February & 43 & 44 & 31 & 24 & 47 & 28 & 32 & 249 & 35 \\
\hline March & 28 & 50 & 32 & 49 & 38 & 31 & 30 & 258 & 37 \\
\hline Total & 443 & 467 & 433 & 455 & 493 & 385 & 368 & 3044 & 435 \\
\hline Invalid filings & $(61)$ & $(27)$ & $(24)$ & $(42)$ & $(12)$ & $(6)$ & $(5)$ & $(177)$ & $(25)$ \\
\hline BR ended & $\underline{320}$ & $\underline{298}$ & $\underline{269}$ & $\underline{250}$ & $\underline{288}$ & $\underline{184}$ & $\underline{82}$ & $\underline{1691}$ & 242 \\
\hline $\begin{array}{l}\text { Active } \\
\text { 31 March 2018 }\end{array}$ & $\underline{62}$ & $\underline{\underline{142}}$ & $\underline{\underline{140}}$ & $\underline{\underline{163}}$ & $\underline{\underline{193}}$ & $\underline{\underline{195}}$ & $\underline{\underline{281}}$ & $\underline{\underline{1176}}$ & \\
\hline
\end{tabular}

Source: Researchers' synthesis of the CIPC data on business rescue firms. 
The fundamental idea is that competencies must be taught to achieve professionalism. Montazemi, Siam and Esfahanipour (2008) emphasise specialist knowledge and skills as the critical drivers of professionalism. Teaching professionalism has been noted to be less formal, and that professionalism is a learned behaviour (Henderson, Jackson, Simmons \& Edwards, 2012; Wagner, 2012). Learning professionalism may be complicated within the MPB setting, and the advocacy for esoteric skills and knowledge ignores professionalism as a practitioner's essence of being in an occupation.

Table 2: Categories of licensed BRP as of 30 September 2020

\begin{tabular}{|c|c|c|c|c|}
\hline & & \multicolumn{3}{|c|}{ Licence category } \\
\hline Professional body & Total & Junior & Senior & Experienced \\
\hline Association of Chartered and Certified Accountants (ACCA) & 2 & 2 & & \\
\hline The Chartered Institute of Management Accountants (CIMA) & 6 & 3 & & 3 \\
\hline Cape Law Society (CLS) & 7 & 5 & & 2 \\
\hline The Institute of Accountants in Commerce (IAC) & 6 & 4 & 0 & 2 \\
\hline The Institute of Business Advisors Southern Africa (IBASA) & 7 & 2 & 3 & 2 \\
\hline The KwaZulu-Natal Law Society (KZNLS) & 5 & 3 & 1 & 1 \\
\hline The Law Society of the Northern Provinces (LSFS) & 3 & 3 & & \\
\hline The Law Society of the Northern Cape (LSNP) & 20 & 12 & 4 & 4 \\
\hline $\begin{array}{l}\text { The South African Institute for Business Accountants } \\
\text { (SAIBA) }\end{array}$ & 20 & 16 & 1 & 3 \\
\hline SAICA & 98 & 35 & 36 & 27 \\
\hline $\begin{array}{l}\text { The Southern African Institute of Professional Accountants } \\
\text { (SAIPA) }\end{array}$ & 15 & 11 & 2 & 2 \\
\hline The Legal Practice Council of South Africa & 50 & 31 & 11 & 8 \\
\hline SARIPA & 77 & 53 & 16 & 8 \\
\hline BRA-SA & 43 & 18 & 8 & 17 \\
\hline Total classified licensees as of 30 September 2020 & 359 & 198 & $\underline{82}$ & 79 \\
\hline Total classified licensees as of 30 September 2019 & $\underline{199}$ & $\underline{99}$ & $\underline{52}$ & $\underline{48}$ \\
\hline Practitioners not linked to a PB as of 30 September 2019 & $\underline{264}$ & $\underline{148}$ & $\underline{52}$ & $\underline{69}$ \\
\hline Percentage (30 September 2020) & $100 \%$ & $55,15 \%$ & $22,8 \%$ & $22,05 \%$ \\
\hline
\end{tabular}

Source: A research synthesis of CIPC BRP registration list as of 30 September 2020.

Studies before 2004 show conflicting definitions of professionalism. Some authors view professionalism as a component of ethics (Shafer, 2002: 272). The making of professionalism as a component of ethics presupposes that teaching ethics results in training practitioners on professionalism. Other authorities link humility and honesty to professionalism so that professionalism is absent whenever honesty and humility are non-existent (Bartels, Pruyn, De Jong \& Joustra, 2007; Henning, Ram, Malpas, Sisley, Thompson \& Hawken, 2014; Howard, 2007). Fatemi, Hasseldine, and Hite (2020) argue that practitioners act with professionalism when they adhere to a code of professional conduct (CPC), and therefore, professionalism is not a principle of ethics. Van De Camp et al. (2004) demonstrate that professionalism has three dimensions, namely interpersonal (working towards proper and fit conduct with clients and colleagues), public (fulfilling the demands placed on the profession), and intrapersonal (being able to meet the demands of the profession).

Evans (2011: 855) contends that professionalism has behavioural (what practitioners perform at work and speaks to the work processes, procedures, work outputs, and competence), attitudinal (attitudes that considers practitioner perception, assessment, motivation to work), and intellectual (practitioners' knowledge structure, understanding, and application) dimensions. Once again, differences in the construction of professionalism seem to be evident. We agree with the perspective that professionalism is about a practitioner's essence of being at a workplace. A practitioner's essence of being perspective emphasises what practitioners do in their working life. In the working life of an expert, we expect experts to develop relationships, deploy improved tools and technology, and create knowledge structures such as required services, codes governing practice behaviour, and the quality of service or work output. 


\section{Problem statement}

Text Box 1 highlights complaints to the CIPC and shows unacceptable acts perpetrated by BRPs. The CIPC has since worked with PBs to come up with the business rescue CPD policy (CIPC, 2020). The questions worth asking are: How has professionalism been constructed among BRP-supplying PBs? Does the constitution of the business rescue CPD policy lead to shared professionalism among practitioners from different PBs? There is no consensus on the meaning of professionalism. Consequently, the construction of professionalism must be understood among the BRP-supplying PBs so that the public can understand what professionalism refers to within the BRP occupation. The lack of consensus on professionalism is bound to affect the criteria of professional standards that can direct the BRPs' work and mitigate against unprofessional acts (Text Box 1).

The current exploratory study sought to take the first step to document constructed professionalism and build mechanisms to direct the BRP professional accreditation regime. The unprofessional acts cited in Text Box 1 read together with the business rescue CPD policy point out that professionalism is lived in every occupation as a practitioner's essence of being in a work context. Practitioners develop professionalism and the same cannot be enforced as a performance contract from a regulatory body (Evans, 2011)

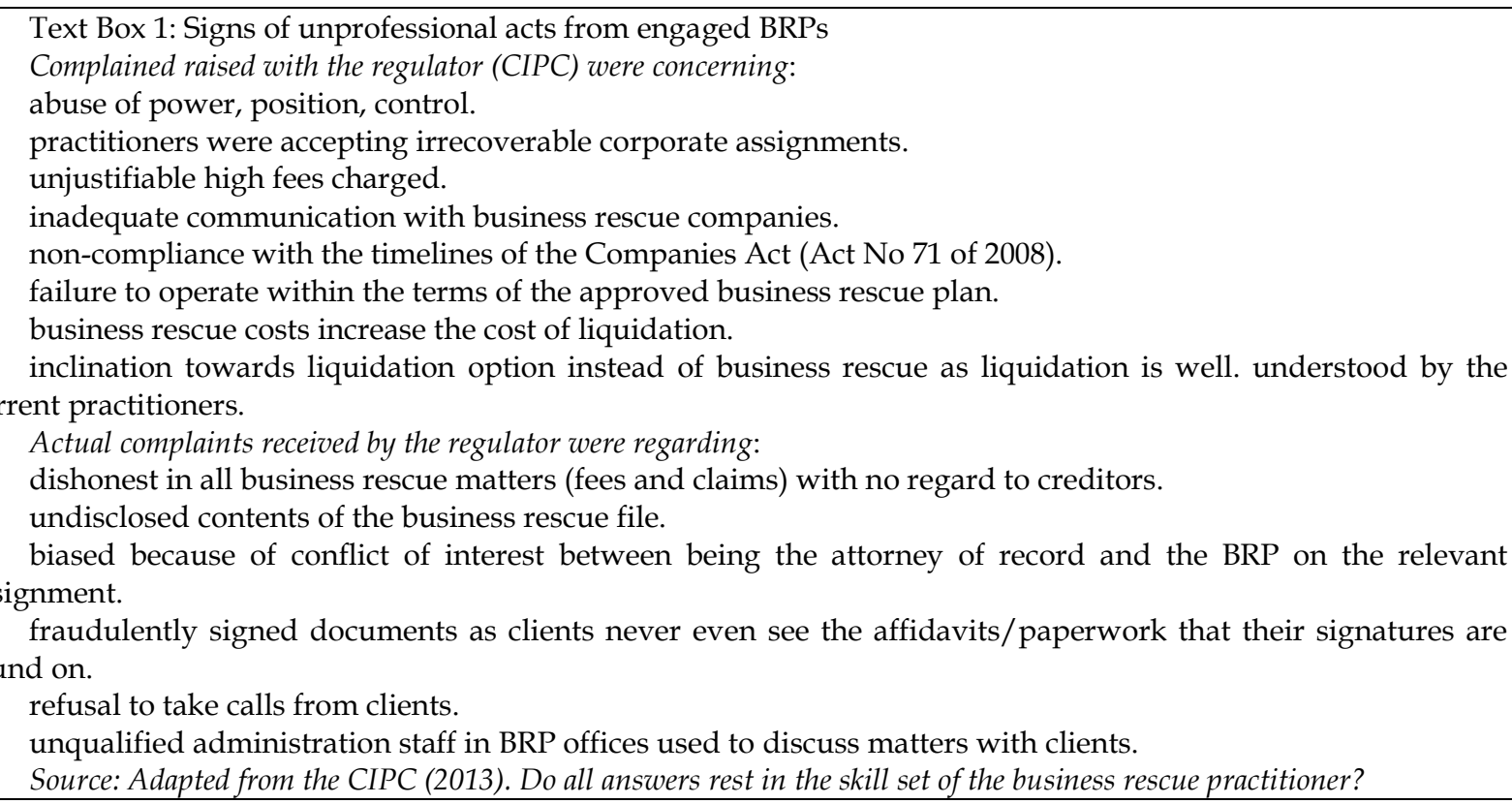

\section{Research questions}

The study explores the following questions:

1. How do PBs providing BRPs construct professionalism, and to what extent can the existing construction of professionalism facilitate the development of a professional accreditation regime?

2. How can constructed professionalism from existing literature contribute to the practical investigation and development of a BRP accreditation framework?

\section{Research design}

Yin (2017) contends that research purpose and questions are the starting points to formulate a research design. The study explores the construction of professionalism within the work of BRPs. This exploration precedes the development of a professional accreditation framework (including a certification) that supports the intents of the Act. Firstly, we interviewed the dominant PBs' representatives to document the professionalism theme from the dominant $\mathrm{PBs}^{\prime}$ perspective. This approach is premised on the institutionalist perspective on professional work and existential ontology (Muzio, Brock, \& Suddaby, 2013; Sandberg \& Pinnington, 2009). Interviews with the representatives of PBs were complemented by content analysis of the four CPCs from the four PBs. The CIPC's business 
rescue continuing professional development (CPD) policy requires accredited PBs to meet out sanctions against their members for misconduct. The disciplinary regime for a PB is contained in the enabling law or CPC.

The qualitative content analysis of the four CPCs was followed by a content analysis of the literature on professionalism. We analysed scholarly pieces of literature to gauge the extent to which the PBs' construction of professionalism are supported by international literature and to respond to the second research question. Table 3 summarises the research design and is accompanied by a detailed description of the design elements.

In attempting to answer the research questions, we were conscious of our own beliefs, philosophical inclinations, and operational values. These assumptions influenced how the research was conducted. An ontological stance embraces the researchers' view on the nature and spirit of the investigative activity and reality. The researchers investigated a socially constructed phenomenon given the MPB landscape. The MPB setting creates a reality that is dependent on the actors in the corporate turnaround. Therefore, we assumed that the practitioners supplying PB contribute to the notions of professionalism through their participation in the CIPC's business rescue liaison committee. We sought to establish recurring mentions of professionalism themes. Our research curiosity was to explore the construction of professionalism as the basis to ground the development of a professional accreditation framework. The business rescue CPD policy shows the importance of professional competence and requires accredited PBs to organise and monitor CPD for their members.

Researchers' theory of knowledge (epistemology) describes how one can discover underlying principles about social phenomena and demonstrate knowledge (Wahyuni, 2012: 69). Notions of professionalism are bound to have subjective meanings, and we focused on the details of the situation as we attempted to understand the reality behind the details. The details are with representatives of the PBs and other official documents addressing professional standards matters. Our personal experience with a business failure and the training of experts ignited our interest in the phenomenon investigated. As academics and experienced turnaround consultants, we prefer realistic regulatory regime directing practices. We structured data-gathering methods to moderate against possible biases arising from our background.

\section{Research methods}

The research design followed in this current work is summarised in Table 3. The nature of the research question dictates the use of qualitative research procedures. Qualitative research procedures are apt to unearth and develop insights into the phenomenon under study, primarily when the phenomenon is poorly understood (Kolsaker, 2008: 515; Yin, 2017). Professionalism is poorly defined for meaningful application to the BRP occupation. Therefore, qualitative methods were deemed suitable to explore the construction of professionalism. The study had four components to it. The first component was based on interviews with member services managers/CEOs of the four PBs supplying $81 \%$ of registered BRPs. The interviews were guided by an interview instrument that was shared with the informants before the day of the virtual meeting. The representatives of the PBs completed the data collection instruments to gauge the scope of the study. One of the researchers scheduled a virtual session, which lasted 2 hours, to discuss the informants' responses in the instrument. The instrument covered aspects such as the existence of a CPC, support provided to the members serving as BRPs, a professional development regime, a disciplinary and sanctions regime, the scope of professional services rendered, higher education courses offered to qualifying candidates, and the definition of professional responsibilities. The responses captured from the informants are summarised in Table 4. 
Table 3: Research design

\begin{tabular}{|c|c|}
\hline Component & Description \\
\hline Problem & $\begin{array}{l}\text { There exists conflicting and incoherent application of professionalism among } \\
\text { BRP-supplying PBs. }\end{array}$ \\
\hline Research question & How should professionalism be constructed for BRPs in a MPB setting? \\
\hline Context & $\begin{array}{l}\text { Regulated BRP regime emerged in the SA setting after the promulgation of the } \\
\text { Companies Act (Act No. } 71 \text { of 2008). TMPs drawn from multiple PBs can apply for } \\
\text { practitioner licences. The CIPC has noted unprofessional acts perpetrated by the } \\
\text { TMPs. The socialisation of BRPs from different PBs is not the same, and, therefore, } \\
\text { the construction and application of professionalism can vary. }\end{array}$ \\
\hline Propositions* & $\begin{array}{l}\text { Increased interest in professionalism has not been accompanied by a coherent } \\
\text { construction and application of professionalism. } \\
\text { Service standards and tasks dictate the notions of professionalism and can be } \\
\text { used to manage fluidity of the construct in a MPB setting. }\end{array}$ \\
\hline $\begin{array}{l}\text { Phenomenon } \\
\text { investigated }\end{array}$ & The construction of notions of professionalism. \\
\hline $\begin{array}{l}\text { Unit of observation } \\
\text { and analysis }\end{array}$ & $\begin{array}{l}\text { Phrases used in the CPC and scholarly literature on professionalism. Responses } \\
\text { from representatives of PBs. }\end{array}$ \\
\hline Methodology & $\begin{array}{cccc}\text { Constant comparison approach using structured } & \text { interviews } & \text { with } \\
\text { representatives of PBs and search of scholarly literature. } & & \\
\end{array}$ \\
\hline $\begin{array}{l}\text { Logic linking the } \\
\text { data to the propositions }\end{array}$ & $\begin{array}{l}\text { Practitioners embrace a sense of being in a workplace. The TMPs can construct } \\
\text { professionalism to gain a practitioner essence of being in an occupation. A } \\
\text { practitioner's essence of being can be gained from the needs served and tools used } \\
\text { to serve. Practitioners use CPCs and ethics to discern what is acceptable standards } \\
\text { because the CPC should be reflecting a practitioner's being at a workplace. } \\
\text { Sensemaking, premised on a practitioner essence of being in an occupation, should } \\
\text { help the researcher investigate and document the construction of professionalism. }\end{array}$ \\
\hline $\begin{array}{c}\text { Criteria for } \\
\text { interpreting the findings }\end{array}$ & $\begin{array}{l}\text { Constant comparison approach to create themes that show emerging notions of } \\
\text { professionalism and their relationship to professional accreditation regime. }\end{array}$ \\
\hline \multicolumn{2}{|c|}{$\begin{array}{l}\text { Source: Yin, R. K. (2018). Case study research and applications: Design and methods (6 }{ }^{\text {th }} \text { Ed). London: Sage } \\
\text { publications Limited. }\end{array}$} \\
\hline
\end{tabular}

We complemented the interview results with content analysis of the CPC and policy statements published by the four PBs. The content analysis of the CPCs and published policy statements established evidence of common themes used by the four dominant PBs in the BRP space. We used an iterative process to classify statements reflecting notions of professionalism. The emerging notions of professionalism or phrases were used to do a literature search in the third component of the study. We examined the policy statements appearing on the selected PBs' websites for specified thematic content or other professionalism expressions. This consideration of thematic content was necessary to establish consistency between a PB's policy statements and the associated CPC. The results of this process are summarised in Table 5.

The third component dealt with document content analysis of the literature on professionalism. We selected literature from databases with a wealth of scholarly literature on professionalism published from 2005 to 2020. The qualitative content analysis of scholarly literature provided us with an abundance of publications on the subject and an opportunity to interrogate professionalism as perceived in the international community within economics, law, and management. The search of scholarly literature and content analysis occurred over eight months. The choice of the period 2005-2020 was informed by the fact the CIPC should have considered the professionalism construct that was most recent (five years old or less) to inform regulated BRPs when the Act was promulgated in 2008 and implemented on 1 May 2011.

The third component of the study proceeded in two phases to achieve the necessary rigour and attach more context to the interview results (Table 4). We studied literature to discern notions of professionalism cited in the definition and accounts of the concept in each selected article. We then scrutinised the notions 
of professionalisms using the constant comparison procedure to uncover the themes within the identified essentials of professionalism. The results are shown in Table 6.

The fourth component of the study was to integrate the results of the preceding study components to advance a framework for the construction, investigation, and documentation of occupation professionalism. The MPB could have its own ways of constructing professionalism. To achieve coherence within the BRP occupation, an integrated framework was needed to help the accredited bodies converge in their construction of notions of professionalism. The convergence point targets a BRP professional accreditation framework. The validation of the notions of professionalism can be expected to occur through the adoption of a professional accreditation framework.

The literature quest entailed searching in the Ebhost and the JSTOR databases for articles published from 2005 to 2020. The search headings were premised on the results identified in the first and second components of the study. The topics we identified in the interview results with informants from the four PBs also helped shape the search topics. The interview results and content analysis of the CPC revealed what PBs envisage practitioners to acquire through learning and development processes.

The search headings, therefore, included 'professionalism and attitude', 'professionalism and independence', 'professionalism and ethics', 'professionalism and identity', 'professionalism and honesty', 'professionalism and commitment', 'professionalism and education', 'professionalism and integrity', 'professionalism and competence', 'professionalism and objectivity', 'professionalism and services', 'professionalism and responsibility', 'professionalism and altruism', 'professionalism and humanism', 'professionalism and regulation', 'professionalism and probity', 'professionalism and confidentiality', 'professionalism and values', 'professionalism and education', and 'professionalism and judgement'. This search process yielded the article in the bibliography.

\section{Data analysis after coding}

The coding of the notions of professionalism provided ground to examine possible themes of professionalism using the constant comparison approach (Kolb, 2012: 84). During the first component of the study, we compared data from the interviews. We asked questions about what value information was in relation to the CPCs and policy statements or enabling legislation. We identified different feature categories (notions) and magnitudes from the data. The constant comparison approach entailed an iterative aspect process of scrutinising and comparing diverse notions of professionalism from different informants, CPCs, and scholars to provide emerging themes. The emergence of a theme was evident from recurring examples across data. We then examined the emerging themes in the literature in relation to the interviews results with PB representatives and the content analysis of the existing CPCs of the four PBs used in the BRP process. Discrepancies in the codes were addressed and resolved through discussions with the representative of the PBs and by examining how professionalism should be constructed in the BRP space. The results are in Table 7. During this process, we were able to test if an emerging picture of professionalism were valid and whether additional aspects should be explored and added. There was no need to add other informants from other PBs as no new notions of professionalism would have emerged.

\section{Results and discussion}

Professionalism and associated elements from interviews

Different continents have different approaches to professionalism, as evident in the overemphasis of character traits of professions in the United States instead of professional behaviour and attitudes (Van Mook et al., 2009). Trait theory has thrived side by side with the social closure strategies that advocate for professional occupations to demonstrate professionalism through (1) exercising self-control as exercised in through autonomy, collegiality and special knowledge and expertise (Bell \& Cowie, 2001); (2) command esoteric expertise learned through prolonged training after high school (Freidson, 2001); (3) performing professional tasks that have a social value (Pareto, 2017); (4) admission members seeking to influence notions of social value (Askary, 2006); and (5) use of ethical code to regulate professional practice (Wright, 2008).

Because of the recognised continental differences in the construction of professionalism alluded to in the literature, we held interviews with representatives of four PBs whose members serve as BRPs. Table 4 presents the unpacked results of the interviews with the representatives of four PBs. The interviews show 
that the BRP occupation lacks a specific qualification with learning outcomes addressing a BRP service delivery package and tasks. The knowledge base and structure are likely to disintegrate among the different BRP-supplying PBs. However, we noted that efforts had been initiated to offer short courses as part of CPD events. The short courses are non-credit bearing and do not contribute to certificates of competence.

The TMA's SA chapter distinguishes itself as the only PB whose members focus on BRP-related work. The other PBs offer BRP-related services along with other services as defined in their respective CPCs. The SARIPA members were historically known for liquidation services. Because BRP-related work is in addition to the other services offered by PBs' members, the PBs have worked on a policy that encourages collaboration among the members of various professional bodies to offer and enforce uniform CPD events (CIPC, 2020).

The CPD events are designed to develop practitioners' understanding and knowledge in the BRP field and its tools. The selected PBs relies significantly on practice notes from the CIPC (the regulator) and have not developed practice tools to enhance members' practice standards. For example, there was no mention of an engagement letter and business rescue plan as practice tools. Published training materials for learning and development are non-existent. Those interviewed battled to refer us to a textbook relevant to the BRP discipline, which continues to be treated like any other business advisory service.

The accountancy and legal profess have three-year traineeship requirements for candidates seeking professional certification. The trainees who enter traineeship agreements gain practical training within legal or accountancy practice firms. The practice firms in these fields do not concentrate on BR services. The value of developing pipeline talent through mentorship contracts was acknowledged but has not been adequately extended to the BRP occupation. The list of licensed BRPs from different PBs is accessible. However, no attempts have been made to link trainees to licensed BRPs for trainees to be mentored on BRP matters. This situation is likely to limit the development of a pipeline talent in BRP matters. The absence of a mentorship arrangement could be compounded by the acknowledged lack of a competency framework from the PBs providing learning outcomes on BRP.

The selected PBs lack established standards and practices to manage and control the quality of work expected from BRPs. Reliance is placed on the legislated checks and balances linked to the stakeholder participation and the need for an aggrieved party to petition the high court in instances of practitioner misconduct. The four PBs contacted do not provide a peer review mechanism of practitioners work on a turnaround assignment. The CIPC commands inadequate capacity to do inspections of BR engagements performed by licensed practitioners. Those interviewed noted that the CIPC is the regulatory body for the licensed BRPs and may be required to undertake quality control tasks regarding the work of licensed BRPs.

There are different processes of professional socialisation (the acquisition of values, attitudes, skills, and knowledge) relevant to BRP culture that PBs have adopted. The process ranges from drawing members from accredited teaching faculties at recognised higher education institutions to CPD events. Two of the PBs contacted made use of short courses (CPD events) as a mechanism for practitioners' socialisation relevant to BRP work. The use of CPD events for BRPs socialisation does not equate to the socialisation during higher education training at accredited teaching faculties in higher education institutions.

Two of the PBs concentrate on liquidation and business rescue as their unique area of work. The legal and accountancy PBs embrace the work done by the SARIPA, including bankruptcy and insolvency, and BRA-SA as business advisory services. The situation diminishes the uniqueness of the selling proposition of the practitioners from the accredited bodies.

Professionalism and associated essentials from codes of ethics

There is representative literature on how to analyse CPCs. Notably, Gaumnitz and Lere (2002) investigated the content of CPCs for professional organisations representing the economics, law and management disciplines of accountancy, human capital, computer information technology, risk management, marketing and sales, operations management, and real estate. Gaumnitz and Lere (2004) built on their 2002 study to formulate a systematic framework for analysing CPCs using a numerical presentation to reflect six attributes of CPCs. These attributes of CPCs pertain to thematic content, tone, 
and structural form (level of detail and shape). In this study, we were interested in substance over form instead of the structural forms of professional codes of conduct and PBs' policy statements that impact occupation practice. We employed centring resonance and textual analysis. Resonance and textual analysis use linguistics theory to assess main concepts, their influence, and their interrelationships (Canary \& Jennings, 2008; Dooley, 2016).

Table 5 presents the results of the analysis of the four CPCs and explores whether common values are evident by qualitatively analysing the four CPCs. This also enabled us to establish how individual PBs have used the CPCs to frame professionalism. We found that three of the PBs do not refer to corporate turnaround or business rescue as a core area of service for their members. Their scope of services tended to include services other than BRP services. The PBs have made no attempts to reference the legislated rescue requirements in their respective CPCs. In addition, matters regarding the professional appointment, acceptance, and termination of BR engagements are not explicitly highlighted to address unprofessional acts like those in Text Box 1 . None of the four CPCs analysed allow practitioners specific discretion powers regarding professional fee determination.

Fundamental ethical principles for professional conduct covered in the analysed CPCs included integrity, fairness, honesty, confidentiality, technical competence, and independence. Yiu (2008) contends that professional ethics are linked to professionalism as standards of professional behaviour. Therefore, professional ethics go beyond the legal and individual moral standards to embrace tort (negligence) law evident in the requirements for competence and duty of due care. The reviewed CPCs emphasise social values, enhancing trust by avoiding conflict of interests, and professional responsibilities, such as collaboration, self-regulation, and mutual respect.

It is evident from Table 5 that professionalism within an occupation is constructed with reference to work outputs, the work done, practices shouldered, attitudes in dealings with others, and intellectual underpinnings, such as knowledge base, structure, acquisition, degree of evidence-based reasoning, comprehensive understanding of knowledge, and build-in problem-solving mechanisms-notions of professionalism as constructed from Table 5 point to the need for professionalism in every occupation. Professionalism comes to life whenever practitioners' shoulders work practices to provide a defined work output or service. All four CPCs provide a scope of professional services. This finding is consistent with Evans's (2011: 855) contention that professionalism is about a practitioner's essence of being in a work context. Ethics can, therefore, be seen as an ingredient of professionalism, and the latter should not be treated as an ethical principle.

Professionalism and its essentials from the selected literature

We completed the search for literature using key phrases to access the relevant literature. We qualitatively analysed the contents of the selected articles. We examined the references of the selected articles for missing scholarly articles. The selected articles were further sorted using an inclusion criterion that required the selected article to be relevant to the field of economics, law, and management. Articles relating to health professionals, engineering, and architecture were excluded. In addition, the selected articles had to contain a description or a definition of professionalism. We were able to identify distinct definitions and meanings attached to professionalism and its essential elements. The adopted selection process resulted to 192 scholarly articles that were related directly to the aim of our study and are included in the bibliography. The list of references only contains sources that are cited in the text write up. Descriptions in the selected literature referring to 'integrity and competence' as 'values in professionalism' compelled us to code 'competence' and 'integrity' as distinct notions of professionalism.

Content analysis of the selected articles established that scholars lack a shared definition of the notion of professionalism. Several articles listed professionalism as a principle of a code of ethics. The explanations offered for the nature of professionalism are diverse in their cited components and their descriptive details. Instances in which professionalism was defined in a sentence and with reference to the CPCs or ethics were noted. Other scholars offered more than four components of professionalism. In only 117 cases were constituent notions of professionalism covered in the articles. In 75 cases, the constituent notions of professionalism were taken for granted and had to be inferred from the context in which they were raised. We found less than explicit definitions of professionalism in articles dealing with professional ethics 
education as they assumed a shared understanding of professionalism as a principle of professional, ethical conduct.

Table 4: Results from the structured interviews

\begin{tabular}{|c|c|c|c|c|}
\hline Item & Law Society & SAICA & SARIPA & TMA-SA \\
\hline $\begin{array}{l}\text { Contents of current } \\
\text { syllabus and its relevance } \\
\text { to BRP. } \\
\text { [Dealings with the PB- } \\
\text { what is the knowledge } \\
\text { structure, the understanding } \\
\text { and acquisition of esoteric } \\
\text { knowledge and skills] }\end{array}$ & 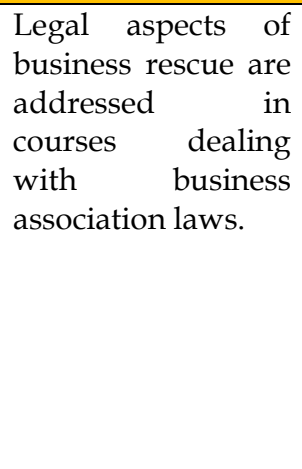 & $\begin{array}{l}\text { Specific } \\
\text { accountancy } \\
\text { qualifications } \\
\text { offered by } \\
\text { accredited } \\
\text { universities. No } \\
\text { content on business } \\
\text { rescue. }\end{array}$ & $\begin{array}{l}\text { No qualification } \\
\text { because } \\
\text { membership } \\
\text { open to more one } \\
\text { specialisation. } \\
\text { Reference made } \\
\text { of the University } \\
\text { of Pretoria's (UP) } \\
\text { one-year } \\
\text { Certified Rescue } \\
\text { Analyst } \\
\text { qualification }\end{array}$ & 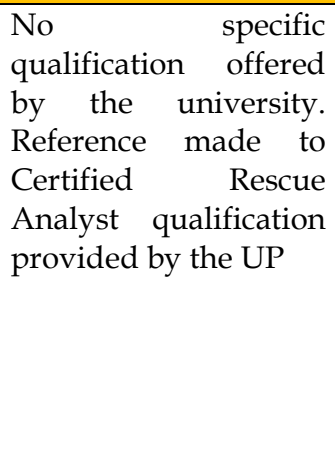 \\
\hline $\begin{array}{l}\text { Unique selling } \\
\text { proposition from the PB. } \\
\text { [Dealing with others in a } \\
\text { distinguishable way] }\end{array}$ & $\begin{array}{l}\text { Legal } \quad \text { services: } \\
\text { litigation, notary, } \\
\text { and conveyancing. }\end{array}$ & $\begin{array}{l}\text { Chartered } \\
\text { accountancy with a } \\
\text { focus on audit } \\
\text { assurance, tax, and } \\
\text { business advisory. } \\
\text { Business rescue } \\
\text { follows under } \\
\text { business advisory }\end{array}$ & $\begin{array}{l}\text { The SARIPA } \\
\text { reckons to be the } \\
\text { largest PB in SA } \\
\text { in the BR } \\
\text { occupation and } \\
\text { participates in the } \\
\text { solvency and } \\
\text { restructuring } \\
\text { activities } \\
\text { worldwide. }\end{array}$ & $\begin{array}{l}\text { Business rescue and } \\
\text { BR services. Affected } \\
\text { parties } \quad \text { preferring } \\
\text { BRA-SA }\end{array}$ \\
\hline $\begin{array}{l}\text { Distinguished services } \\
\text { offered by the PB. } \\
\text { [Dealings with work tasks } \\
\text { and services] }\end{array}$ & $\begin{array}{l}\text { Legal services as } \\
\text { defined in the legal } \\
\text { practice } \\
\text { Members } \\
\text { undertake work } \\
\text { according to a } \\
\text { client's brief. }\end{array}$ & $\begin{array}{l}\text { Auditing, } \\
\text { accounting, } \\
\text { independent } \\
\text { review, } \\
\text { management } \\
\text { consulting, and } \\
\text { financial } \\
\text { management. } \\
\text { Members } \\
\text { undertake work } \\
\text { according to the } \\
\text { letter of } \\
\text { engagement and } \\
\text { plan }\end{array}$ & $\begin{array}{l}\text { The SAQA } \\
\text { recognises } \\
\text { SARIPA for its } \\
\text { insolvency and } \\
\text { rescue services. } \\
\text { Members have } \\
\text { been appointed } \\
\text { in the BRP } \\
\text { matters to date. }\end{array}$ & $\begin{array}{l}\text { Members off BRP } \\
\text { services. The BRA-SA } \\
\text { is a professional } \\
\text { association and does } \\
\text { not take on work done } \\
\text { by lawyers, } \\
\text { accountants, auditors, } \\
\text { etc. outside the BR } \\
\text { process. Members } \\
\text { undertake work } \\
\text { according to a rescue } \\
\text { plan }\end{array}$ \\
\hline $\begin{array}{l}\text { The PB's support to } \\
\text { members serving as BRPs. } \\
\text { [Dealings with the } P B \text { ] }\end{array}$ & \begin{tabular}{lr}
\multicolumn{2}{l}{ Reliance placed on } \\
practice notes \\
issued by the CIPC. \\
Ensuring good \\
standing $r$ of \\
members to meet \\
accreditation \\
requirements.
\end{tabular} & $\begin{array}{l}\text { CPD help members } \\
\text { gain insights into } \\
\text { BRP practices, } \\
\text { prepares a letter of } \\
\text { good standing for } \\
\text { the member to } \\
\text { obtain BRP licence, } \\
\text { disciplinary for } \\
\text { misconduct, } \\
\text { monitoring the } \\
\text { CPD activities. }\end{array}$ & $\begin{array}{l}\text { Regular Webinars } \\
\text { on BR practices, } \\
\text { practice notes } \\
\text { and case law } \\
\text { updates. }\end{array}$ & $\begin{array}{l}\text { There are numerous } \\
\text { practice notes } \\
\text { covering topics that } \\
\text { range from initiating } \\
\text { business rescue to } \\
\text { reasonable prospect to } \\
\text { the charging of fees. } \\
\text { Tools for planning, } \\
\text { reporting to court and } \\
\text { CIPC emerge from } \\
\text { CIPC practice notes. }\end{array}$ \\
\hline $\begin{array}{l}\text { Practice tools available to } \\
\text { members serving as BRPs. } \\
\text { [Dealing with work tasks: } \\
\text { how services are rendered] }\end{array}$ & $\begin{array}{l}\text { The CIPC- } \\
\text { developed practice } \\
\text { notes and circulars. } \\
\text { Rescue plans as per } \\
\text { the Act. }\end{array}$ & $\begin{array}{l}\text { The CIPC- } \\
\text { developed practice } \\
\text { notes and circulars. } \\
\text { No specific tools } \\
\text { used as in the case } \\
\text { of audit assurance. }\end{array}$ & $\begin{array}{l}\text { The members } \\
\text { rely on the CIPC- } \\
\text { developed } \\
\text { practice notes } \\
\text { and circulars. } \\
\text { Rescue plan as }\end{array}$ & $\begin{array}{l}\text { The CIPC-developed } \\
\text { practice notes and } \\
\text { circulars. Members } \\
\text { prepare rescue plans } \\
\text { to guide BRP } \\
\text { assignments. }\end{array}$ \\
\hline
\end{tabular}




\begin{tabular}{|c|c|c|c|c|}
\hline Item & Law Society & SAICA & SARIPA & TMA-SA \\
\hline & & $\begin{array}{l}\text { Rescue plan as per } \\
\text { the Act. }\end{array}$ & per the Act. & \\
\hline $\begin{array}{l}\text { Support training } \\
\text { materials are known and } \\
\text { used in the development } \\
\text { of members practising as } \\
\text { BRPs. [Dealing with the PB: } \\
\text { Knowledge understanding } \\
\text { and acquisition] }\end{array}$ & $\begin{array}{l}\text { Case law book, } \\
\text { relevant legislation. }\end{array}$ & $\begin{array}{l}\text { Members uses any } \\
\text { available course } \\
\text { materials used in } \\
\text { CPD events. }\end{array}$ & $\begin{array}{l}\text { Detailed courses } \\
\text { presented at the } \\
\text { University of } \\
\text { South Africa and } \\
\text { the UP. }\end{array}$ & $\begin{array}{l}\text { There are no specific } \\
\text { recommended } \\
\text { textbooks. There is a } \\
\text { certified rescue } \\
\text { analyst course that } \\
\text { BRA-SA developed } \\
\text { jointly with the UP. A } \\
\text { good book is } \\
\text { "Corporate From } \\
\text { Restructuring: Falysis to } \\
\text { Cause Analy } \\
\text { Execution by David } \\
\text { Vance". }\end{array}$ \\
\hline $\begin{array}{l}\text { Established training } \\
\text { contracts and mentorship } \\
\text { on BRP-specific matters. } \\
\text { [Dealing with work tasks } \\
\text { and services: Development } \\
\text { of skills to the quiddity of } \\
\text { BRP] }\end{array}$ & $\begin{array}{l}\text { No mentorship or } \\
\text { traineeship } \\
\text { agreements were } \\
\text { specifically } \\
\text { addressing BRP } \\
\text { matters. }\end{array}$ & $\begin{array}{l}\text { None. The SAICA } \\
\text { has a register of } \\
\text { BRPs, which is } \\
\text { published, and } \\
\text { trainees can use it } \\
\text { to establish contacts } \\
\text { with accomplished } \\
\text { membership for } \\
\text { mentoring. }\end{array}$ & $\begin{array}{l}\text { Current } \\
\text { mentorship is not } \\
\text { formalised } \\
\text { because aspiring } \\
\text { young BRP's are } \\
\text { welcome to the } \\
\text { SARIPA for } \\
\text { assistance in } \\
\text { identifying } \\
\text { mentoring } \\
\text { opportunities. }\end{array}$ & $\begin{array}{l}\text { No formal mentorship } \\
\text { programme. } \\
\text { Mentorship occurs } \\
\text { with the UP course } \\
\text { that covers business } \\
\text { finance, tax law, } \\
\text { business management, } \\
\text { and professional } \\
\text { ethics }\end{array}$ \\
\hline $\begin{array}{l}\text { Established standards and } \\
\text { practices to manage and } \\
\text { control the quality of } \\
\text { work expected from } \\
\text { BRPs. } \\
\text { [Dealing work tasks and } \\
\text { services-what is the } \\
\text { required work behaviour] }\end{array}$ & $\begin{array}{l}\text { Seeking a second } \\
\text { opinion on matters } \\
\text { in which the } \\
\text { practitioner lacks } \\
\text { competence. }\end{array}$ & $\begin{array}{l}\text { The CPC } \\
\text { (requirement 113) } \\
\text { requires that the } \\
\text { BRP not to } \\
\text { undertake } \\
\text { engagement the } \\
\text { BRP is not } \\
\text { competent to } \\
\text { perform. unless the } \\
\text { practitioner obtains } \\
\text { advice and } \\
\text { assistance. }\end{array}$ & $\begin{array}{l}\text { Reliance is placed } \\
\text { on the legislated } \\
\text { checks and } \\
\text { balances and } \\
\text { stakeholder } \\
\text { participation and } \\
\text { petitions to the } \\
\text { high court. }\end{array}$ & $\begin{array}{l}\text { None. Review occurs } \\
\text { when instances of } \\
\text { misconduct are } \\
\text { brought to the fore. } \\
\text { The BRA-SA a code } \\
\text { ethics and practice } \\
\text { standard have been } \\
\text { published. These two } \\
\text { combined with the } \\
\text { accreditation policy } \\
\text { are the key policies in } \\
\text { respect of quality of } \\
\text { work and } \\
\text { benchmarking. }\end{array}$ \\
\hline $\begin{array}{l}\text { Established professional } \\
\text { codes and competency } \\
\text { framework applicable to } \\
\text { BRPs. } \\
\text { [Dealings with the public, } \\
\text { clients, and others] }\end{array}$ & $\begin{array}{l}\text { Professional } \\
\text { principle and Legal } \\
\text { Professional } \\
\text { Practice Act apply } \\
\text { to attorneys and } \\
\text { advocates. }\end{array}$ & $\begin{array}{l}\text { The CPC contains } \\
\text { requirements } \\
\text { dealing with } \\
\text { business advisory } \\
\text { services. } \\
\text { Competency } \\
\text { framework exists } \\
\text { for Chartered } \\
\text { Accountants BRP } \\
\text { without } \\
\text { specifics. }\end{array}$ & $\begin{array}{l}\text { The PB does not } \\
\text { have a distinct } \\
\text { competency } \\
\text { framework for } \\
\text { those seeking } \\
\text { membership. }\end{array}$ & $\begin{array}{l}\text { On the website, there } \\
\text { is a code ethics and } \\
\text { practice standard that } \\
\text { is published. The two } \\
\text { documents go } \\
\text { together with the } \\
\text { accreditation policy, } \\
\text { specifying the } \\
\text { qualifications required } \\
\text { to apply for } \\
\text { membership. }\end{array}$ \\
\hline $\begin{array}{l}\text { Established process of } \\
\text { professional socialisation } \\
\text { to acquire values, }\end{array}$ & $\begin{array}{l}\text { Training of lawyers } \\
\text { from accredited } \\
\text { faculties, training }\end{array}$ & $\begin{array}{l}\text { Training of } \\
\text { chartered } \\
\text { accountants }\end{array}$ & $\begin{array}{l}\text { Short courses } \\
\text { offered by the } \\
\text { University of }\end{array}$ & $\begin{array}{l}\text { The member } \\
\text { accreditation policy } \\
\text { refers to conference, }\end{array}$ \\
\hline
\end{tabular}




\begin{tabular}{|c|c|c|c|c|}
\hline Item & Law Society & SAICA & SARIPA & TMA-SA \\
\hline $\begin{array}{l}\text { attitudes, skills, and } \\
\text { knowledge. [Dealing with } \\
\text { others: perceptions, beliefs } \\
\text { and views held; people's } \\
\text { values; and people's } \\
\text { motivation, occupation } \\
\text { satisfaction and morale] }\end{array}$ & $\begin{array}{l}\text { firms. There is a } \\
\text { common platform } \\
\text { for CPD for } \\
\text { lawyers. }\end{array}$ & $\begin{array}{l}\text { accredited schools } \\
\text { of accountancy and } \\
\text { training firms. } \\
\text { Besides, there is a } \\
\text { common platform } \\
\text { for CPD events. }\end{array}$ & $\begin{array}{l}\text { South Africa, the } \\
\text { University of } \\
\text { Johannesburg } \\
\text { and the UP. No } \\
\text { limitations to } \\
\text { unstructured } \\
\text { networking } \\
\text { opportunities. }\end{array}$ & $\begin{array}{l}\text { annual BRA-SA } \\
\text { events, and the } \\
\text { Certified Rescue } \\
\text { Analyst course offered } \\
\text { by UP are used to } \\
\text { entrench values, } \\
\text { attitudes, and skills. }\end{array}$ \\
\hline
\end{tabular}

\section{Emerging themes from the literature and interview results}

As seen in Table 6, we recognised a total of 38 constituent notions of professionalism. It is interesting to note that professional ethics, ethical conduct, technical knowledge, professional code, specialised knowledge and expertise, integrity, autonomy, commitment, standards-based work and education, and certifications were highlighted most frequently. The findings seem consistent with the perspective that professionalism is about a practitioner's essence of being in an occupation. The emerging themes of dealings with clients, dealings with PBs, dealings with the public and dealings with oneself resonate with the perspective of professionalism as a consideration of a practitioner gaining from a work context. The work context (not SAQA-recognised bodies) is what defines work practices and service.

The four emerging themes of professionalisms (Table 7) are linked to the different notions of professionalism reflected in Tables 4,5 and 6 . Table 7 provides a brief description of the themes in column 3. The integration of results in Table 7 shows that professionalism is not about the professional competence that has enjoyed attention from the CIPC, which recently issued a business rescue CPD policy.

Table 5: Focus of professional codes of ethics and constitutions

\begin{tabular}{|c|c|c|c|c|}
\hline Item & Law Society & SAICA & SARIPA & TMA-SA \\
\hline Scope of professional services & $\sqrt{ }$ & $\sqrt{ }$ & $\sqrt{ }$ & $\sqrt{ }$ \\
\hline Meaning of BR practice or business rescue practice & & & $\sqrt{ }$ & $\sqrt{ }$ \\
\hline BRP tasks outlined & & & & $\sqrt{ }$ \\
\hline Integrity and honesty as ethical principles & $\sqrt{ }$ & $\sqrt{ }$ & $\sqrt{ }$ & $\sqrt{ }$ \\
\hline Objectivity as an ethical principle & $\sqrt{ }$ & $\sqrt{ }$ & $\sqrt{ }$ & $\sqrt{ }$ \\
\hline Professional competence and qualifications & $\sqrt{ }$ & $\sqrt{ }$ & $\sqrt{ }$ & $\sqrt{ }$ \\
\hline Due care and skill exercised during work & $\sqrt{ }$ & $\sqrt{ }$ & $\sqrt{ }$ & $\sqrt{ }$ \\
\hline Professional confidentiality given as an ethical principle & $\sqrt{ }$ & $\sqrt{ }$ & $\sqrt{ }$ & $\sqrt{ }$ \\
\hline Professional behaviour and reputation & $\sqrt{ }$ & $\sqrt{ }$ & $\sqrt{ }$ & $\sqrt{ }$ \\
\hline Professional independence & $\sqrt{ }$ & $\sqrt{ }$ & $\sqrt{ }$ & $\sqrt{ }$ \\
\hline Conflict of interest to discouraged to enhance trust & $\sqrt{ }$ & $\sqrt{ }$ & $\sqrt{ }$ & $\sqrt{ }$ \\
\hline \multicolumn{5}{|l|}{ Links to the legislated corporate turnaround requirements } \\
\hline Public interest and relationship with the PB & $\sqrt{ }$ & $\sqrt{ }$ & $\sqrt{ }$ & $\sqrt{ }$ \\
\hline Links to the PB's constitution and by-laws & $\sqrt{ }$ & $\sqrt{ }$ & $\sqrt{ }$ & $\sqrt{ }$ \\
\hline Membership and subscription fees & $\sqrt{ }$ & $\sqrt{ }$ & $\sqrt{ }$ & $\sqrt{ }$ \\
\hline Disciplinary structures, meaning of misconduct and sanctions & $\sqrt{ }$ & $\sqrt{ }$ & $\sqrt{ }$ & $\sqrt{ }$ \\
\hline Requirements for members to comply with laws and regulations & $\sqrt{ }$ & $\sqrt{ }$ & $\sqrt{ }$ & $\sqrt{ }$ \\
\hline $\begin{array}{l}\text { Professional appointment and acceptance (engagement letters } \\
\text { and client briefs) }\end{array}$ & $\sqrt{ }$ & $\sqrt{ }$ & $\sqrt{ }$ & $\sqrt{ }$ \\
\hline The discretion granted in respect of charging professional fees & $\sqrt{ }$ & $\sqrt{ }$ & & \\
\hline $\begin{array}{l}\text { Members encouraged to seek second opinion or use third parties } \\
\text { on complex assignments }\end{array}$ & $\sqrt{ }$ & $\sqrt{ }$ & $\sqrt{ }$ & $\sqrt{ }$ \\
\hline Restricted marketing and advertising of services & $\sqrt{ }$ & $\sqrt{ }$ & & \\
\hline
\end{tabular}

Source: Researchers' synthesis of available codes of professional conduct.

The matter is not addressed explicitly in the policy and the CPC. 
Table 6: Essentials of professionalism used scholarly definitions and descriptions.

\begin{tabular}{|c|c|c|c|}
\hline Public interest & 45 & Public image/prestige/reputation & 44 \\
\hline Attitudes & 31 & Professional appearance/dress code & 16 \\
\hline Public trust & 44 & Confidence & 15 \\
\hline $\begin{array}{l}\text { Personal values / subjective } \\
\text { characteristic }\end{array}$ & 25 & Commitment/devotion & 77 \\
\hline $\begin{array}{l}\text { Work in the interest of clients } \\
\text { (focus) }\end{array}$ & 44 & Responsibilities & 47 \\
\hline 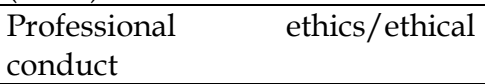 & 86 & Mutual recognition, Courtesy and respect & 30 \\
\hline Professional code & 80 & Standards-based work and education & 86 \\
\hline $\begin{array}{lll}\begin{array}{l}\text { Substance } \\
\text { knowledge }\end{array} & \text { of } & \text { specialist } \\
\end{array}$ & 111 & $\begin{array}{lll}\begin{array}{l}\text { Professional } \\
\text { knowledge }\end{array} & \text { development/continual } & \text { updating } \\
\end{array}$ & 36 \\
\hline $\begin{array}{l}\text { Quality:(dependable) work } \\
\text { outputs }\end{array}$ & 45 & Evidence-based practice & 18 \\
\hline Professional abilities & 25 & Teamwork and collaboration/collegiality & 31 \\
\hline Technical competence/skills & 91 & Certification/licence & 64 \\
\hline $\begin{array}{lll}\begin{array}{l}\text { Technological } \\
\text { practice) }\end{array} & \text { (methods of } \\
\end{array}$ & 28 & Body of practice & 16 \\
\hline Experienced and maturity & 26 & Accountability & 42 \\
\hline Objectivity & 21 & Accreditation and stringent entry requirements & 34 \\
\hline Independence & 43 & Probity & 23 \\
\hline Integrity & 73 & Honesty & 42 \\
\hline $\begin{array}{l}\text { Judgement (making decisions in } \\
\text { complex situations) }\end{array}$ & 32 & & \\
\hline Altruism/social values & 29 & & \\
\hline Client advocacy & 29 & & \\
\hline Fairness & 32 & & \\
\hline $\begin{array}{l}\text { Self- } \\
\text { regulation/policing/direction }\end{array}$ & 58 & & \\
\hline Autonomy & 101 & & \\
\hline
\end{tabular}

Source: Researchers' content analysis of selected articles published during 2005-2020.

Dealings with clients - BR entities and clients

Dealings with clients recognise notions of professionalism that help the practitioner to provide legislated services effectively. The notions of professionalism in this theme give preconditions for effective and adequate contact with a BR entity and its stakeholders. The notions cover the need to have a cordial relationship with the client's BR entity. Educating the client on rescue options and the design of plans are essential. A few other notions of professionalism within this theme are relevant to dealings with stakeholders and other team members during a rescue operation. The nature of the work practice may lead to the demonstration of notions of 'dealings with clients' when a practitioner interacts with staff at a business rescue site and enlists the help of other experts.

Dealing with clients relates to what a practitioner does during a BR process. We, therefore, expect the notions of professionalisms to include work processes, procedures, productivity, and skills. A professional occupation comes into existence to render services and outputs that expertly meet clients' needs. To this end, Fatemi et al. (2018: 140) maintain that "most practitioners assume their clients prefer tax-saving strategies, even when not explicitly requested" and undertake tasks that favour clients. 
Table 7: Emerging themes from dimensions of professionalism

\begin{tabular}{|c|c|c|}
\hline Theme & Aspects & Descriptions \\
\hline $\begin{array}{l}\text { Dealings } \\
\text { with the PB }\end{array}$ & $\begin{array}{l}\text { Collaborating with community of experts } \\
\text { Competence and specialist knowledge } \\
\text { Self-regulation and direction } \\
\text { Professional reputation } \\
\text { Continuous training and development } \\
\text { Certification and licensing } \\
\text { Methods of professional practice } \\
\text { Mentoring of trainees }\end{array}$ & $\begin{array}{l}\text { The theme is about a practitioner fulfilling the } \\
\text { requirements regarding professional } \\
\text { commitments to the } \mathrm{PB} \text { and peers in the BR } \\
\text { field. }\end{array}$ \\
\hline $\begin{array}{l}\text { Dealings } \\
\text { with clients } \\
\text { to provide } \\
\text { services } \\
\text { (work tasks) }\end{array}$ & $\begin{array}{l}\text { Independent work } \\
\text { Competence, due care, and skill } \\
\text { Honesty and integrity } \\
\text { Dedication and commitment } \\
\text { Quality of outputs and services } \\
\text { Evidence-based advice } \\
\text { Trusted experts } \\
\text { Confidentiality \& respect } \\
\text { Compassion and polite in relationships } \\
\text { Educate clients on options available. } \\
\text { Respect clients' right of shared decision making. } \\
\text { Subservient self-interests }\end{array}$ & $\begin{array}{l}\text { The theme is about a practitioner fulfilling the } \\
\text { work practice requirements of occupation's } \\
\text { purpose, status, specific nature and range and } \\
\text { levels of service. }\end{array}$ \\
\hline $\begin{array}{l}\text { Dealings } \\
\text { with the } \\
\text { public, } \\
\text { including } \\
\text { government } \\
\text { and others }\end{array}$ & $\begin{array}{l}\text { Fairness and transparency } \\
\text { Trusted expert } \\
\text { Standards-based work and training } \\
\text { Mutual recognition and respect } \\
\text { Accountability } \\
\text { Submission to an ethical code } \\
\text { High level of expertise } \\
\text { Methodological and thoroughness } \\
\text { Technical competence } \\
\text { Enhancing the welfare of the society } \\
\text { Protect confidential information. } \\
\text { Commitment to contribution of business to society } \\
\text { Expert authority } \\
\text { Autonomy of professional associations }\end{array}$ & $\begin{array}{l}\text { The theme is about a practitioner fulfilling the } \\
\text { requirements society imposes on the } \\
\text { sanctioned occupation. }\end{array}$ \\
\hline $\begin{array}{l}\text { Dealings } \\
\text { with oneself }\end{array}$ & $\begin{array}{l}\text { Demonstrated maturity. } \\
\text { Confidence and self-conception } \\
\text { Dress code and appearance } \\
\text { Continuing professional development } \\
\text { Value corporate renewal work } \\
\text { Unimpaired judgement } \\
\text { Professional scepticism } \\
\text { Response to stress and self-awareness } \\
\text { Critical analysis }\end{array}$ & $\begin{array}{l}\text { The theme is about a practitioner fulfilling the } \\
\text { requirements to operate in the BR practice } \\
\text { field as a practitioner. }\end{array}$ \\
\hline
\end{tabular}

Dealings with professional associations

Dealings with professional associations constitute a theme because the CIPC requires practitioners to be members in good standing with their PBs. In terms of section 138 of the Companies Act (Act No. 71 of 2008) of SA, a person may only be appointed as a BRP if the person is a member in good standing of a legal, accounting or business management PB accredited by the CIPC. The CIPC's requirement, as set out in Notice No. 2 of 2019, is that the pre-requisite to be registered as a BRP is that the person must obtain a letter of good standing from their PB. Representatives of the PBs believe a practitioner dealing with the PB are important given the CPCs and the associated relational aspects.

This theme encompasses professionalism notions that pertain to prerequisites for becoming a member of a PB and remaining in good professional standing. Staying relevant and up to date in the field is as important as gaining admission. Some of the notions of professionalism in this theme relate to working 
with colleagues, undertaking peer review work and CPD events, and contributing to the professional reputation. Other notions within this theme cover structured dealings with colleagues. Most notions are deemed relevant as part of a practitioner's essence of being in an occupation.

Dealings with the public and others

The third emerging theme puts together notions of professionalism that guide a practitioner's dealings leading to the fulfilment of the requirements that society, through Parliament, places on the BRP occupation. It deals with standards-based training and work practices and a trusted expert that is not conflicted. An illustration of these notions can be found in the work of Fatemi et al. (2018: 134), who contend that "... codes of conduct apply to all members but ... practitioners, in particular, are cast in a unique role of serving the public interest with their accountability to both clients and tax agencies (among other stakeholders)".

Public trust and interest obligate SAQA-recognised PBs to know relevant laws, to undertake practical and transparent self-regulation and to support the development of pipeline talent. Therefore, compared to dealings with the clients' theme, this theme addresses context values and requirements associated with the regular monitoring of professional commitments.

\section{Dealings with oneself}

The fourth theme relates to the dealings with oneself and addresses requirements that a practitioner must fulfil to operate adequately in the business rescue profession as an individual. The notion of dealing with oneself involves personal characteristics or behaviours that are deemed to impact the way an individual practitioner operates. This theme raises the role of attitudinal behaviour in professionalism as supported by Askary (20006) and Creasy (2015: 24), who argued that professional behaviours are observable actions that demonstrate the expert's appropriate behaviours modelling of the appearance, attitudes, self-management, and timeliness in the pursuit service. Examples of descriptions of elements of dealings with oneself are "courage, temperance or self-control, and justice-along with related moral virtues such as humility, integrity, patience, courtesy, modesty, and liberality" (Lail, MacGregor, Marcum, \& Stuebs, 2017: 696). Representatives of the PBs expressed the need for practitioner socialisation through CPD events as a vehicle practitioner can use to gain a sense of belonging to the occupation.

\section{Towards occupational professionalism construction and documentation}

The results from interviews with the selected PB representatives, content analysis of the four CPCs and scholarly literature point to professionalism construction emphasising practitioner essence of being within the occupation. The emerging dimensions of the practitioner essence of being in an MPB context require a professionalism construction and documentation framework.

Figure 1 sets out the programmatic way of constructing, investigating and documenting professionalism to achieve the practitioner essence of being within the BRP occupation. Figure 1 (reading from top to down) begins with an understanding of BRP services and tasks from regulatory requirements in a jurisdiction and the results of interviews with practitioners. Pretorius (2014) recognises the existence of a BRP legal framework used to outline BRP tasks. Purposive interpretation of regulatory requirements can be employed to understand and document legislative services and tasks. Results from purposive interpretation can be complemented by the double results from interviews with members of the community of practitioners in the BRP occupation. The suggested process is envisaged to contribute to the inherent nature (quiddity) of professionalism. Occupations exist to serve needs, and fulfilling the needs creates the practitioner's essence of being.

Rajaram and Singh (2018) emphasise the importance of professional competence and confirm the efforts required to identify and develop BRPs' professional competence relevant to practitioners' work and services. The services and tasks are evident from service package objectives, tools, methods of work and work organisation. BRPs' tasks and services can be discerned from the legislative requirements and the CPCs subjected to purposive interpretation during the research process. In the present study, the BRPs' tasks and services were not confirmed by representatives of the four major PBs.

The arrows in Figure 1 show the interrelationships among different framework components. From the top-down in Figure 1, we argue that desired services dictate tasks shouldered by BRPs. These tasks 
and service packs should help come up with an expert BRP profile and other ingredients of the PAF. The tasks shouldered to provide services inform professional competences, which can be used to develop learning and development resources (human capital investments) required to support professional accreditation. Professional accreditation is needed to deal with BRP licensing and to link BRPs to a PB. Therefore, services are required help define the BRP discipline boundaries for accreditation and certification purposes. The desired CPD regime should fall within the defined BRP discipline boundaries.

It will be unexpected for BRP professionalism to be constructed and developed outside a professional accreditation and certification process and without defining the theory and practice claim covered by the BRP professional certification. Professional training that is informed by a PAF and certification activities define the notions of professionalism. Professionalism founded on services, tasks, methods, expertise, and ethics becomes relevant after BRPs have claimed their ability to perform at defined standards, as articulated in the professional accreditation regime. Professional learning and development interventions can be facilitated by PBs and higher education institutions to develop competent BRPs. Dealings with others in learning and development enhance the practitioner's essence of being in an occupation, and therefore, higher education institutions and PBs serve as critical sources of data to develop the professional accreditation regime.

\section{Conclusion}

We argued that professionalism is about a practitioner's essence of being in an occupation context. The PBs supplying BRPS construct professionalism differently (Tables 4 and 5). This has implications for the exercising of professionalism in the corporate turnaround assignments. The CIPC, through its regulations and CPD policy (CIPC, 2020), advocates for professionalism in the BRP occupation. However, the difficulty remains in understanding, identifying, constructing, and documenting professionalism in an occupation context. Figure 1 summarises these aspects and points to integrated data collection procedures in the design of a PAF. The emerging relational perspective of professionalism as constituted by a practitioner's essence of being in an occupation suggests that the CIPC moves away from specialist knowledge and skills towards a practitioner's dealings with oneself, the public, PBs, and clients. Using such elucidations of professionalism lead to informed choices on professional accreditation, learning and development. The integrated exploration supports the notion that our understanding of professionalism is fragmented if the BRP fails to link brains and hands power to tools of the trade, needs to be served by practitioners, professional behaviour, and professional attitude to others.

The article's key contribution is to interpretatively explore the constructed meaning of professionalism as an organising framework for the MPBs shouldering BRP work. It provides a pragmatic path for the construction and documentation of professionalism (Figure 1). It also enhances the professionalism literature by exploring how the concept is understood and socially constructed within the scholarly literature. We examined notions of professionalism within an existing MPB landscape from the perspective of a practitioner's essence of being in an occupation to enhance BRP professionalism in an integrated way.

\section{Implications}

Our examination revealed that a practitioner dealing with the client (given services required), the PB, the public and others, and oneself contribute to a practitioner's essence of being in the work context. The defined dealings are relevant in the delineation of the BRP as a discipline worth of professional and academic pursuit. We conclude that professionalism is a multidimensional construct and relational within the MPB occupation setting. The multidimensional aspects of professionalism led us to explore a pragmatic approach to constructing, investigating, and documenting professionalism in the BRP occupation (Figure 1). This is important in the design of a professional accreditation framework to create a uniform basis of practitioner learning and development.

The different PBs are not bound up with similar socially constructed notions of professionalism. Some of the PBs have a history of providing business consultancy services alongside other services. Such PBs have notions of professionals that reflect the business rescue profession as an additional service that add to their members' already embraced notions. Moreover, the social construction of professionalism is linked to the practitioners' essence of being at the workplace, which starts with higher education training. 
Therefore, the notions of dealings with clients, government, and others, PBs, and oneself in the context of the business rescue profession cannot be divorced from the past. Models of BRPs' tasks and services are based on the legislated requirements, and practitioners' explanations of practices, ethics and values are key to the refinement of the BRP occupation. The findings of the study point to the need for a pragmatic framework to help construct, understand, document, and investigate what constitutes professionalism in the BRP occupation. Theories on professionalism and professional competence emphasise specialist knowledge, skills, and work performance to the exclusion of a practitioner's essence of being in the work context.

\section{Limitations of the study and directions for future research}

The conclusion is derived from interviews with the PBs' representatives and content analysis of CPCs and scholarly literature. Currently licensed BRPs were not interviewed. Therefore, detailed interviews for double and purposive interpretation are needed to provide a grounded basis for the construction, understanding and investigating professionalism as an organising framework for practitioners drawn from MPBs. Purposive interpretation is pertinent to future research because the BRP occupation is a regulated practice. The understanding of BRP practices requires purposive interpretation of the legal prescripts on the BR process.

Practitioners in communities of practice have not been used to suggest how professionalism can be enacted comprehensively through experience. Furthermore, investigations are needed to establish professional trajectories regarding occupational practice specifics, including business rescue strategies and turnaround risks. Another aspect worth investigating is how PBs vary in ways of practising business rescue management and how this reflects the more comprehensive international practices. An additional issue is to investigate the degree to which professionalism is the fundamental vehicle for enhancing professional practice in emerging fields. Such investigations may require a historical exposition of a practitioner's essence of being through different stages of an occupation's evolution.Figure 1: Pragmatic construction and documentation of professionalism. 


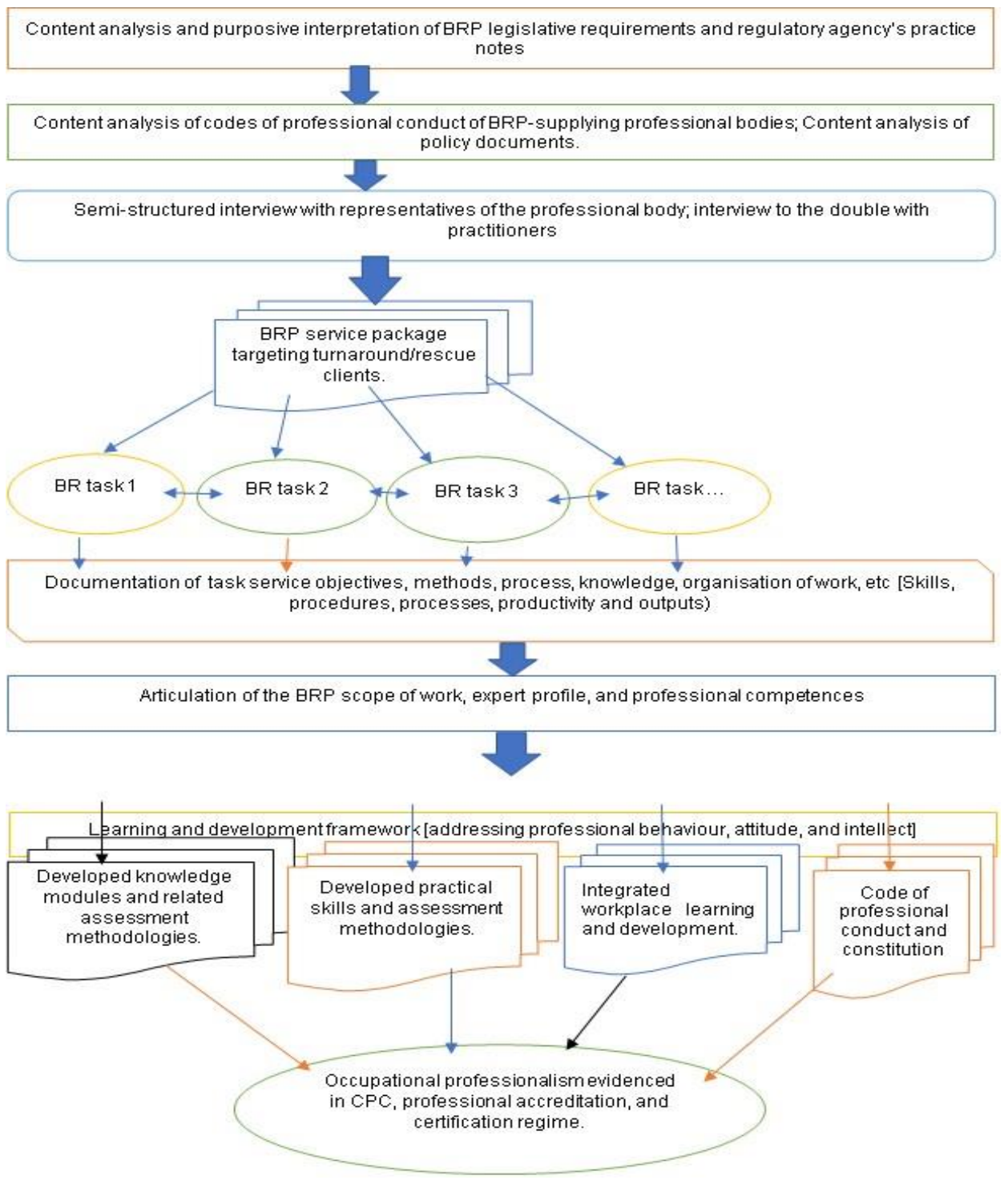

References

Arnold, L. (2002). Assessing professional behavior: yesterday, today, and tomorrow. Academic medicine, 77(6), pp. 502515.

Askary, S. (2006). Accounting professionalism-a cultural perspective of developing countries. Managerial auditing journal, 21(1/2), pp. 102-111.

Bartels, J., Pruyn, A., De Jong, M. and Joustra, I. (2007). Multiple organizational identification levels and the impact of perceived external prestige and communication climate. Journal of Organizational Behavior: The International Journal of Industrial, Occupational and Organizational Psychology and Behavior, 28(2), pp. 173-190.

Bell, B. and Cowie, B. (2001). The characteristics of formative assessment in science education. Science education, 85(5), pp. 536-553.

Canary, H. E., and Jennings, M. M. (2008). Principles and influence in codes of ethics: A centering resonance analysis comparing pre-and post-Sarbanes-Oxley codes of ethics. Journal of Business Ethics, 80(2), pp. 263-278.

CIPC (2013). Do all answers rest in the skill set of the business rescue practitioner? Pretoria: Unpublished presentation.

CIPC (2020). Business rescue continuing professional development policy. Government Gazetter No. 882, pp. 24-32

Dooley, K. J. (2016). Using manifest content analysis in purchasing and supply management research. Journal of Purchasing and Supply Management, 22(4), pp. 244-246.

Evans, L. (2011). The 'shape' of teacher professionalism in England: Professional standards, performance management, professional development and the changes proposed in the 2010 White Paper. British educational research journal, 37(5), 851-870. 
Evetts, J. (2000). The European professional federations: occupational regulation in European markets. Discussion paper Centre for Professions and Professional Work, School of Sociology and Social Policy. University of Nottingham, UK.

Evetts, J. (2003) The sociological analysis of professionalism: occupational change in the modern world. International Sociology, 18(2), 395-415.

Fatemi, D., Hasseldine, J., and Hite, P. (2020). The Influence of ethical codes of conduct on professionalism in tax practice. Journal of Business Ethics, 164(1), 133-149.

Freidson, E. (2001). Professionalism: the third logic, London: Polity Press

Gaumnitz, B. R. and J. C. Lere (2002). Contents of Codes of Ethics of Professional Organizations in the United States, Journal of Business Ethics, 35(1), pp.35-50

Gaumnitz, B. R. and J. C. Lere: 2004, A Classification Scheme for Codes of Business Ethics, Journal of Busi-ness Ethics, 49(4), pp. 329-335.

Henderson, D., Jackson, V., Simmons, S., and Edwards, D. W. (2012). Preparation for Successful Clinical Experiences: A Collaborative Perspective on Internship Orientation. Journal of Best Practices in Health Professions Diversity: Education, Research \& Policy, 5(1), pp. 774-789

Henning, M. A., Ram, S., Malpas, P., Sisley, R., Thompson, A., and Hawken, S. J. (2014). Reasons for academic honesty and dishonesty with solutions: a study of pharmacy and medical students in New Zealand. Journal of medical ethics, 40(10), pp. 702-709.

Howard, G. R. (2007). Dispositions for good teaching. Journal of Educational Controversy, 2(2), pp. 191-198.

Kolb, S. M. (2012). Grounded theory and the constant comparative method: Valid research strategies for educators. Journal of emerging trends in educational research and policy studies, 3(1), pp. 83-86.

Kolsaker, A. (2008) Academic professionalism in the managerialist era: a study of English universities, Studies in Higher Education, 33(5), pp. 513.

Lail, B., MacGregor, J., Marcum, J., and Stuebs, M. (2017). Virtuous professionalism in accountants to avoid fraud and to restore financial reporting. Journal of business ethics, 140(4), pp. 687-704.

Macheridis, N. and Paulsson, A., 2019. Professionalism between profession and governance: how university teachers' professionalism shapes coordination. Studies in Higher Education, 44(3), pp.470-485.

Montazemi, A. R., Siam, J. J., and Esfahanipour, A. (2008). Effect of network relations on the adoption of electronic trading systems. Journal of Management Information Systems, 25(1), pp. 233-266.

Muzio, D., Brock, D. M., and Suddaby, R. (2013). Professions and institutional change: Towards an institutionalist sociology of the professions. Journal of management studies, 50(5), pp. 699-721.

Pareto, V. (2017). The rise of professionalism: Monopolies of competence and sheltered markets. Routledge.

Pretorius, M. (2014). A competency framework for the business rescue practitioner profession. Professional Accountant, 14(2), pp. 1-15.

Rajaram, R., and Singh, A. M. (2018). Competencies for the effective management of legislated business rehabilitations. South African Journal of Economic and Management Sciences, 21(1), pp. 1-9.

Sandberg, J., and Pinnington, A. H. (2009). Professional competence as ways of being: An existential ontological perspective. Journal of management studies, 46(7), 1138-1170.

Shafer, W. E. (2002). Ethical pressure, organizational-professional conflict, and related work outcomes among management accountants. Journal of Business Ethics, 38(3), pp. 261-273.

Van De Camp, K., Vernooij-Dassen, M. J., Grol, R. P., \& Bottema, B. J. (2004). How to conceptualize professionalism: a qualitative study. Medical teacher, 26(8), pp. 696-702.

Van Mook, W. N., van Luijk, S. J., O'Sullivan, H., Wass, V., Zwaveling, J. H., Schuwirth, L. W., and van der Vleuten, C. P. (2009). The concepts of professionalism and professional behaviour: conflicts in both definition and learning outcomes. European Journal of Internal Medicine, 20(4), pp. e85-e89.

Wagner, P. A. (2012). Legal ethics no paradigm for educational administrators. Journal of Thought, 47(1), pp. $21-37$.

Wahyuni, D. (2012). The research design maze: Understanding paradigms, cases, methods, and methodologies. Journal of applied management accounting research, 10(1), pp. 69-80.

Wright, R. (2008). Sexual harassment and professional ethics. The SAA Archaeological Record, 8(4), 27-30.

Yin, R. K. (2018). Case study research and applications: Design and methods (6 $6^{\text {th }}$ Ed). London: Sage publications Limited.

Yiu, C. (2008). A new model to help students develop professional ethics. Journal of Real Estate Practice and Education, 11(1), pp. 41-56.

\section{Bibliography}

Adams, T. L. (2007).). Interprofessional relations and the emergence of a new profession: Software engineering in the United States, United Kingdom, and Canada. The Sociological Quarterly, 48(3), pp. 507-532.

Adams, T. L. (2015). Sociology of professions: International divergences and research directions. Work, employment, and society, 29(1), pp. 154-165. 
Adler, P. S. (2012). Perspective-the sociological ambivalence of bureaucracy: from Weber via Gouldner to Marx. Organization Science, 23(1), pp. 244-266.

Ahmed, M. A. (2016). Pakistan's governance goliath: the case of non-professional Chairman, FTM. The Pakistan Development Review, 55(4), pp. 621-656.

Alexander, E. R. (2005). What do planners need to know? Identifying needed competencies, methods, and skills. Journal of Architectural and Planning Research, pp. 91-106.

Andreassen, T. A., Breit, E., and Legard, S. (2014). The making of 'professional amateurs' Professionalizing the voluntary work of service user representatives. Acta Sociologica, 57(4), pp 325-340.

Askary, S. (2006). Accounting professionalism - a cultural perspective of developing countries. Managerial auditing journal.21(1), pp. 102-111

Avis, J. (2009). Further education: policy hysteria, competitiveness, and performativity. British Journal of Sociology of Education, 30(5), 653-662.

Babcock, D. (2012). Professional Subjectivity and the Attenuation of Character in JM Coetzee's Life \& Times of Michael K. PMLA, 127(4), 890-904.

Banks, S. (2010). Integrity in professional life: Issues of conduct, commitment, and capacity. British Journal of Social Work, 40(7), 2168-2184.

Bannier, B. J. (2008). The Professionalization of Developmental Education: Have We Arrived? Research and Teaching in Developmental Education, 24(2), 3-14.

Barley, S. R., and Kunda, G. (2006). Contracting: A new form of professional practice. Academy of Management Perspectives, 20(1), 45-66

Beck, J. (2008). Governmental professionalism: Re-professionalising or de-professionalising teachers in England? British journal of educational studies, 56(2), 119-143.

Beck, J. (2009). Appropriating professionalism: restructuring the official knowledge base of England's 'modernised' teaching profession. British journal of sociology of education, 30(1), 3-14.

Bezes, P., Demaziere, D., Le Bianic, T., Paradeise, C., Normand, R., Benamouzig, D., \& Evetts, J. (2011). New Public Management and professions in the public administration: Beyond opposition, what new patterns are taking shape? Sociologie du travail, 53(3), pp. 293-348.

Bolton, S., and Muzio, D. (2008). The paradoxical processes of feminization in the professions: the case of established, aspiring, and semi-professions. Work, employment, and society, 22(2), pp. 281-299

Boon, A., Flood, J. and Webb, J. (2005). PosBRodern professions? The fragmentation of legal education and the legal profession. Journal of Law and Society, 32(3), pp. 473-492.

Bramming, P., Sørensen, O. H. and Hasle, P. (2009). In spite of everything: Professionalism as mass customised bureaucratic production in a Danish government call centre. Work Organisation, Labour and Globalisation, 3(1), pp. 114-130.

Brandsen, T. (2009). Civicness in organizations: A reflection on the relationship between professionals and managers. Voluntas: International Journal of Voluntary and Nonprofit Organizations, 20(3), pp. 260-273.

Brannon, S. (2014). Assessment in fieldwork courses: what are we rating? Journal of Education for Library and Information Science, 55(2), pp. 274-302.

Broch, L. (2014). Professionalism in the final solution: French railway workers and the Jewish deportations, 19424. Contemporary European History, pp. 359-380.

Brouard, F., Bujaki, M., Durocher, S., and Neilson, L. C. (2017). Professional accountants' identity formation: An integrative framework. Journal of Business Ethics, 142(2), 225-238.

Burmeister, O. K. (2017). Professional ethics in the information age. Journal of Information, Communication and Ethics in Society, 15(4), pp. 348-356

Caboni, T. C. (2010). The normative structure of college and university fundraising behaviors. The Journal of Higher Education, 81(3), pp. 339-365.

Caena, F. (2014). Teacher Competence Frameworks in Europe: policy-as-discourse and policy-as-practice. European Journal of Education, 49(3), pp. 311-331.

Campbell, E. (2008). The ethics of teaching as a moral profession. Curriculum Inquiry, 38(4), pp. 357-385.

Campbell, H., and Marshall, R. (2005). Professionalism and planning in Britain. Town Planning Review, 76(2), pp. 191215.

Campbell, S. (2014). Erosion and renewal of professional powers in public sector employment: The role of occupational community. Relations Industrielles/Industrial Relations, 69(1), pp. 159-185.

Carliner, S. (2012). The three approaches to professionalization in technical communication. Technical Communication, 59(1), pp. 49-65.

Carliner, S., Castonguay, C., Sheepy, E., Ribeiro, O., Sabri, H., Saylor, C., \& Valle, A. (2015). The job of a performance consultant: a qualitative content analysis of job descriptions. European Journal of Training and Development.39(6), pp. $459-483$ 
Chen, C. H. V., \& Kao, R. H. (2012). Work values and service-oriented organizational citizenship behaviors: The mediation of psychological contract and professional commitment: A case of students in Taiwan Police College. Social Indicators Research, 107(1), pp. 149-169.

Chiu, T. K. (2014). Putting responsible finance to work for Citi microfinance. Journal of Business Ethics, 119(2), pp. 219234

Choi, H. S., Benson, N. F., and Shudak, N. J. (2016). Assessment of Teacher Candidate Dispositions: Evidence of Reliability and Validity. Teacher Education Quarterly, 43(3), pp. 71-89.

Chreim, S., Williams, B. E., and Hinings, C. R. (2007). Interlevel influences on the reconstruction of professional role identity. Academy of Management Journal, 50(6), pp. 1515-1539

Clark, C. (2006). Moral character in social work. British journal of social work, 36(1), pp. 75-89

Cleary, Y. (2012). Discussions about the technical communication profession: Perspectives from the blogosphere. Technical Communication, 59(1), pp. 8-28.

Cline, S. (2009). " To Coppola, N. W., and Elliot, N. (2013). Conceptualizing the technical communication body of knowledge: Context, metaphor, and direction. Technical Communication, 60(4), pp. 267-278.

Cochran-Smith, M., McQuillan, P., Mitchell, K., Terrell, D. G., Barnatt, J., D’Souza, L., and Gleeson, A. M. (2012). A longitudinal study of teaching practice and early career decisions: A cautionary tale. American Educational Research Journal, 49(5), pp. 844-880.

Cottle, M., and Alexander, E. (2012). Quality in early years settings: Government, research, and practitioners' perspectives. British Educational Research Journal, 38(4), pp. 635-654.

Covert, H., Sherman, M., Miner, K., \& Lichtveld, M. (2019). Core competencies and a workforce framework for community health workers: a model for advancing the profession. American journal of public health, 109(2), pp. 320-327

Creek, D. V. (2005). Solomon Huebner and the Development of Life Insurance Sales Professionalism, 19051927. Enterprise \& Society, 6(4), pp. 646-681.

Damon, W., Colby, A., Bronk, K., and Ehrlich, T. (2005). Passion and mastery in balance: toward good work in the professions. Daedalus, 134(3), pp. 27-35.

D'Cruz, P., \& Noronha, E. (2009). Experiencing depersonalised bullying: a study of Indian call-centre agents. Work Organisation, Labour and Globalisation, 3(1), 26-46.

de Bruin, B. (2013). Epistemic integrity in accounting: Accountants as justifiers in joint epistemic agents. Business $\mathcal{E}$ Professional Ethics Journal, 32(1/2), pp. 109-130.

de Bruin, B. (2016). Pledging integrity: Oaths as forms of business ethics management. Journal of Business Ethics, 136(1), pp. 23-42.

De Martino, G. (2013). Professional economic ethics: The Posnerian and Naïve perspectives. Journal of Forensic Economics, 24(1), pp. 3-18.

Demir, T., and Nyhan, R. C. (2008). The politicsa-dministration dichotomy: An empirical search for correspondence between theory and practice. Public Administration Review, 68(1), pp. 81-96.

Desai, R., and Roberts, R. (2013). Deficiencies in the code of conduct: The AICPA rhetoric surrounding the tax return preparation outsourcing disclosure rules. Journal of Business Ethics, 114(3), pp. 457-471

Doyle, L., Egetenmeyer, R., Singai, C., and Devi, U. (2016). Professionalisation as development and as regulation: Adult education in Germany, the United Kingdom and India. International Review of Education, 62(3), pp. 317-341.

Downs, Y. (2013). Chapter 7: Teachers' Lives, Professional Knowledge, Educational Reform. Counterpoints, 441, pp. 6982.

Dunbar, A. M. (2014). Making the Case: Detection and Confession in Lady Audley's Secret and The Woman in White. Victorian Review, 40(1), pp. 97-116.

Du Plessis, C. (2005). The Recurring Governance Crisis: Director Independence and the Disconnect Between Structural Reform and Conduct. Business \& Professional Ethics Journal, 24(4), pp. 83-111.

Dunkle, S. M., and Ahuna, K. H. (2014). Chapter ten: Professional Dispositions for Teacher Candidates: From Standardization to Wisely Effective Classrooms. Counterpoints, 447, 197-211.

Edwards, R., and Nicoll, K. (2006). Expertise, competence, and reflection in the rhetoric of professional development. British Educational Research Journal, 32(1), 115-131.

Evans, T. (2013). Organisational rules and discretion in adult social work. British Journal of Social Work, 43(4), 739-758.

Evans, L. (2008). Professionalism, professionality, and the development of education professionals. British journal of educational studies, 56(1), 20-38.

Evans, T. (2010). Professionals, managers and discretion: Critiquing street-level bureaucracy. The British Journal of Social Work, 41(2), 368-386.

Ehlers, U. D. (2007). Quality Literacy - Competencies for Quality Development in Education and e-Learning. Journal of Educational Technology \& Society, 10(2), 96-108. 
Farrow, T. C. (2014). Residential schools' litigation and the legal profession. University Furlong*, J. (2005). New Labour and teacher education: the end of an era. Oxford Review of Education, 31(1), 119-134.

Faulconbridge, J., and Muzio, D. (2008). Organizational professionalism in globalizing law firms. Work, employment and society, 22(1), 7-25.

Fechter, A. M. (2012). 'Living Well' while 'Doing Good'?(Missing) debates on altruism and professionalism in aid work. Third World Quarterly, 33(8), 1475-1491.

Freeman, N. K., \& Feeney, S. (2006). The new face of early care and education. YC Young Children, 61(5), pp. 10-14.

Frelin, A. (2016). Curriculum, "Didaktik", and Professional Teaching: Conceptual Contributions from the Intersections of Curriculum Studies in an Age of" Crisis" in Education. Counterpoints, 491, pp. 645-662.

Gleeson, D., Davies, J., and Wheeler, E. (2005). On the making and taking of professionalism in the further education workplace. British Journal of Sociology of Education, 26(4), pp. 445-460

Green, B. A. (2007). The market for bad legal scholarship: William H. Simon's experiment in professional regulation. Stan. L. Rev., 60, pp. 1605-1671

Gross, A. C., Holtzblatt, M., Javalgi, R., Poor, J., and Solymossy, E. (2013). Professional occupations, knowledge-driven firms, and entrepreneurship: A national and regional analysis. Business Economics, 48(4), pp. 246-259.

Guimarães, P. (2009). Reflections on the professionalisation of adult educators in the framework of public policies in Portugal. European Journal of Education, 44(2), pp. 205-219.

Guthrie, J. W., and Marsh, D. D. (2009). Introduction to the special issue on the education doctorate. Peabody Journal of Education, 84(1), pp. 1-2.

Hamdani, R., Rahimah, I., and Hafiz, M. S. (2020). Exploring the Professionalism and Dysfunctional Behavior of Public Accountants on Audit Quality. Review of Integrative Business and Economics Research, 9, pp. 9-19.

Hamilton, N., and Brabbit, L. M. (2007). Fostering professionalism through mentoring. Journal of Legal Education, 57(1), pp. 102-129

Hao, Z. (2016). In search of a professional identity: higher education in Macau and the academic role of faculty. Higher Education, 72(1), pp. 101-113.

Harshman, E. M., Gilsinan, J. F., Fisher, J. E., and Yeager, F. C. (2005). Professional ethics in a virtual world: The impact of the internet on traditional notions of professionalism. Journal of Business Ethics, 58(1-3), pp. 227-236.

Hilferty, F. (2008). Theorising teacher professionalism as an enacted discourse of power. British Journal of Sociology of Education, 29(2), pp. 161-173.

Hilferty, F. (2007). Contesting the curriculum: An examination of professionalism as defined and enacted by Australian history teachers. Curriculum Inquiry, 37(3), 239-261.

Hon, T. S. (2010). Birthing the Lawyer: The Impact of three years of law school on law students in the National University of Singapore. Singapore Journal of Legal Studies, pp. 417-458

Holland, L. (2011). Do higher education computing degree courses develop the level of moral judgement required from a profession? Journal of Information, Communication and Ethics in Society, 9(2), pp. 116-126.

Hughes, A. G., and Teodoro, M. P. (2013). Assessing professionalism: Street-level attitudes and agency accreditation. State and Local Government Review, 45(1), pp. 36-45.

Huijts, P. M., De Bruijn, E., and Schaap, H. (2011). Revealing personal professional theories. Quality \& quantity, 45(4), pp. 783-800.

Ibrahim, N., \& Angelidis, J. (2009). The relative importance of ethics as a selection criterion for entry-level public accountants: Does gender make a difference? Journal of Business Ethics, 85(1), pp. 49-58.

Jagger, S. L., \& Yore, L. D. (2012). Mind the gap: Looking for evidence-based practice of science literacy for all in science teaching journals. Journal of Science Teacher Education, 23(6), pp. 559-577

Jarausch, K. H. (2012). The Perils of Professionalism: Lawyers, Teachers, and Engineers in Nazi Germany [1986]. Historical Social Research. Supplement, pp. 157-183.

Jørgensen, T. B. (2006). Public values, their nature, stability and change. The case of Denmark. Public Administration Quarterly, 30(3/4), pp. 365-398.

Kelly, P. (2006). What is teacher learning? A socio-cultural perspective. Oxford review of education, 32(4), pp. 505-519.

Kline, J., and Barker, T. (2012). Negotiating professional consciousness in technical communication: A community of practice approach. Technical Communication, 59(1), pp. 32-48.

Kirby, M. W. (2006). 'A festering sore': the issue of professionalism in the history of the Operational Research Society. Journal of the Operational Research Society, 57(10), pp. 1161-1172.

Kudomi, Y. (2005). Contemporary education reform and teachers: the meaning of their positions in the reform and the transformation of their occupational culture. Hitotsubashi journal of social studies, 37(1), pp. 19-31.

Kultgen, J. (2014). Professional paternalism. Ethical Theory and Moral Practice, 17(3), pp. 399-412

Levin, L. C. (2009). Guardians at the gate: The backgrounds, career paths, and professional development of private US immigration lawyers. Law \& Social Inquiry, 34(2), pp. 399-436. 
Lerman, L. G. (2006). First do no harm: Law professor misconduct toward law students. Jurnal of Legal Education., 56(1), pp. 86-112.

Lindemann, E. (2011). How Well Are We Listening? Lessons from the Founding of NCTE and CCCC. College Composition and Communication, 62(3), pp. 504-539.

Lippman, E. J. (2009). Accountants 'responsibility for the Information They Report: An Historical Case Study of Financial Information. Accounting Historians Journal, 36(1), pp. 61-79.

Liu, S. (2006). Client influence and the contingency of professionalism: the work of elite corporate lawyers in China. Law \& Society Review, 40(4), pp. 751-782.

Lu, X., and Koehn, D. (2015). On responsibility in China: Understanding and practice. Journal of Business Ethics, 127(3), pp. 607-622.

Lo, C. W. H., and Snape, E. (2005). Lawyers in the People's Republic of China: A study of commitment and professionalization. The American Journal of Comparative Law, 53(2), pp. 433-455

Macleod, G., MacAllister, J., and Pirrie, A. (2012). Towards a broader understanding of authority in student-teacher relationships. Oxford Review of Education, 38(4), pp. 493-508

Mah, L. (2005). The legal profession faces new faces: How lawyers' professional norms should change to serve a changing American population. California Law Review, 93(6), pp. 1721-1772.

Maehr, D. S., Thompson, B. C., Mattfeld, G. F., Montei, K., Haufler, J. B., Kerns, J. D., and Ramakka, J. (2002). Directions in professionalism and certification in The Wildlife Society. Wildlife Society Bulletin, 30(4), pp. 12451252.

Malone, E. A. (2011). The first wave (1953-1961) of the professionalization movement in technical communication. Technical Communication, 58(4), pp. 285-306.

Marques, A. P. (2016). Accessing a Profession in the Third Sector Organisations: a Portuguese Case Study. Studi di Sociologia,54(3), pp. 243-261.

Melé, D. (2005). Ethical education in accounting: Integrating rules, values and virtues. Journal of Business Ethics, 57(1), pp. 97-109.

McCallum, C. E. (2006). Professionalism: It's No Joke. Bus. L. Today, 38(2), pp. 16-43.

McCoy, K. E. (2012). Organizational frames for professional claims: Private military corporations and the rise of the military paraprofessional. Social Problems, 59(3), pp. 322-340.

McCraw, H., Moffeit, K. S., and O'Malley, J. R. (2009). An analysis of the ethical codes of corporations and business schools. Journal of business ethics, 87(1), pp. 1-13.

Mescher, B. R. (2008). The business of commercial legal advice and the ethical implications for lawyers and their clients. Journal of Business Ethics, 81(4), 913-926.

Metsch-Garcia, B. (2015). Eliminating Financiers from the Equation: A Call for Court-Mandated Fee Shifting in Divorces. Michigan Law Review, 113(7), pp. 1271-1294.

Miller, P. M., Gibson, J. D., Balslev, G. M., and Scanlan, M. (2012). Looking beyond Harlem: International insights for area-based initiatives: Area-based initiatives in France and the United Kingdom offer lessons for other countries. Middle School Journal, 44(1), pp. 16-24.

Milsom, A., and Akos, P. (2007). National certification: Evidence of a professional school counsellor? Professional School Counseling, 10(4), pp. 346-351.

Nathan, R. (2011). Responsibility of Schools in Dispensing Equal Justice: A Singapore Case Study. Journal of the Indian Law Institute, 53(2), pp. 310-332.

Nilsen, A. S., and Olsen, O. E. (2005). Different strategies-Equal practice? Risk assessment and management in municipalities. Risk Management, 7(2), pp. 37-47.

Ollila, S., Styhre, A., and Werr, A. (2015). Managing knowledge integration: Balancing professional and managerial logics in an engineering consulting firm. German Journal of Human Resource Management, 29(2), pp. 131-148.

Olsen, B., and Sexton, D. (2009). Threat rigidity, school reform, and how teachers view their work inside current education policy contexts. American Educational Research Journal, 46(1), pp. 9-44.

Ottosson, M., and Rosengren, C. (2015). Who can you trust? The Swedish Confederation for Professional Employees (TCO) and trust-based working time 1950-1970. management revue, 26(1), 52-68.

Parikh, S., and Garth, B. (2005). Philip Corboy and the construction of the Plaintiffs' personal injury bar. Law \& Social Inquiry, 30(2), pp. 269-304.

Pearce, R. G., and Uelmen, A. J. (2006). Religious Lawyering's Second Wave. Journal of Law and Religion, 21(2), pp. 269281.

Pethers, M. (2009). This Small Herculean Labor": Literary Professionalism, Georgic Work, and" Walden. American Studies, 54(2), pp. 165-194.

Peytcheva, M., and Warren, D. E. (2011). Auditor professionalism: The importance of internalizing professional standards and detection of severely sanctioned professional violations. Business \& Professional Ethics Journal, 30 (1/2), pp. 33-57 
Petrick, J. A., and Scherer, R. F. (2005). Management educators' expectations for professional ethics development. Journal of Business Ethics, 61(4), pp. 301-314.

Pritchard, K., and Symon, G. (2011). Identity on the line: constructing professional identity in a HR call centre. Work, Employment and Society, 25(3), pp. 434-450.

Purinton, T. (2012). Teachers as professionals: Owning instructional means and negotiating curricular ends. Counterpoints, 425 , pp. 27-44.

Rafael, E. F. (2014). is Sociology in the Philippines a Professionalized Discipline? Philippine Sociological Review, 62, pp. 213-236.

Ranganathan, A. (2013). Professionalization and market closure: The case of plumbing in India. ILR Review, 66(4), pp. 902-932.

Reeves, J., and Boreham, N. (2006). What is in a vision? Introducing an organisational learning strategy in a local authority's education service. Oxford Review of Education, 32(4), pp. 467-486.

Reeves, J. (2007). Inventing the chartered teacher. British Journal of Educational Studies, 55(1), pp. 56-76.

Report of the Task Force on Defining Key Competencies for Business Lawyers, Business Law Education Committee, ABA Business Law Section. (2016). Defining Key Competencies for Business Lawyers. The Business Lawyer, 72(1), pp. 101-156.

Reynolds, J. (2007). Discourses of inter-professionalism. British Journal of Social Work, 37(3), 441-457.

Roberts, L. M. (2005). Changing faces: Professional image construction in diverse organizational settings. Academy of management review, 30(4), 685-711.

Robson, J., \& Bailey, B. (2009). 'Bowing from the heart': an investigation into discourses of professionalism and the work of caring for students in further education. British Educational Research Journal, 35(1), 99-117.

Remus, D. A. (2011). Just Conduct: Regulating Bench-Bar Relationships. Yale L. \& Pol'y Rev., 30, pp. 123.

Rogers, J. (2010). Shadowing the bar: Studying an English professional elite. Historical Reflections/Reflexions Historiques, 36(3), pp. 39-57.

Rogowski, S. (2012). Social work with children and families: Challenges and possibilities in the neo-liberal world. British Journal of Social Work, 42(5), pp. 921-940.

Rusaw, A. C., and Fisher, V. D. (2017). Promoting training and professional development in government: The origins and early contributions of spod. Public Administration Quarterly, 41(2), pp. 216-232.

Rutgers, M. R. (2008). Sorting out public values? On the contingency of value classification in public administration. Administrative Theory \& Praxis, 30(1), pp. 92-113.

Samsonova-Taddei, A., and Siddiqui, J. (2016). Regulation and the promotion of audit ethics: Analysis of the content of the EU's policy. Journal of Business Ethics, 139(1), 183-195.

Sanghera, B., \& Ilyasov, A. (2008). The social embeddedness of professions in Kyrgyzstan: an investigation into professionalism, institutions, and emotions. Europe-Asia Studies, 60(4), 643-661.

Sawicki, N. N. (2008). Doctors, discipline, and the death penalty: Professional implications of safe harbor policies. Yale Law \& Policy Review, 27, pp. 107-160

Scheidt, S., Gelhard, C., Strotzer, J., and Henseler, J. (2018). In for a penny, in for a pound? Exploring mutual endorsement effects between celebrity CEOs and corporate brands. Journal of Product \& Brand Management,27(2), pp. 203-220.

Schurman, R. (2013). Chapter Eight: Is There a Model for Success? Exploring Sustainable Professional Employment among Clinical Exercise Physiology Program's Graduates. Counterpoints, 436, pp. 148-165.

Sciulli, D. (2007). Professions before professionalism. European Journal of Sociology, pp. 121-147.

Schwartz, J., Luce, M. F., and Ariely, D. (2011). Are consumers too trusting? The effects of relationships with expert advisers. Journal of Marketing Research, 48(SPL), S163-S174Servage, L. (2009). Who is the" professional" in a professional learning community? An exploration of teacher professionalism in collaborative professional development settings. Canadian Journal of Education, 32(1), 149-171.

Seery, A. (2008). Ethics and professionalism in teaching. Studies: An Irish Quarterly Review, 97(386), 183-192.

Sekerka, L. E., Bagozzi, R. P., and Charnigo, R. (2009). Facing ethical challenges in the workplace: Conceptualizing and measuring professional moral courage. Journal of Business Ethics, 89(4), pp. 565-579.

Severn, S. (2014). Narrative Cessation and Professional Culture in Elizabeth Gaskell's A Dark Night's Work. Victorian Review, 40(1), pp. 155-175.

Shiveley, J., and Misco, T. (2010). "But how do I know about their attitudes and beliefs?": A four-step process for integrating and assessing dispositions in teacher education. The clearing house: A journal of educational strategies, issues, and ideas, 83(1), pp. 9-14.

Smith, G. S. (2007). Maurice stans 'views on social responsibility in the accounting profession. Accounting Historians Journal, 34(1), pp. 147-172. 
Snow, J. L., Martin, S. D., and Dismuke, S. (2015). “We Do More Than Discuss Good Ideas": A Close Look at the Development of Professional Capital in an Elementary Education Liaison Group. Teacher Education Quarterly, 42(2), 43-63.

Solbrekke, T. D., and Karseth, B. (2006). Professional responsibility-an issue for higher education? Higher Education, 52(1), pp. 95-119.

Sommerlad, H. (2007). Researching and theorizing the processes of professional identity formation. Journal of Law and Society, 34(2), pp. 190-217.

Spence, C., and Carter, C. (2014). An exploration of the professional habitus in the Big 4 accounting firms. Work, Employment and Society, 28(6), pp. 946-962.

Spalding, A. D., and Oddo, A. (2011). It's time for principles-based accounting ethics. Journal of Business ethics, 99(1), pp. 49-59.

Spalter-Roth, R. (2007). Sociologists in research, applied, and policy settings: Bringing professionals in from the cold. Journal of Applied Social Science, 1(2), pp. 4-18.

Spence, C., Carter, C., Belal, A., Husillos, J., Dambrin, C., and Archel, P. (2016). Tracking habitus across a transnational professional field. Work, employment and society, 30(1), pp. 3-20.

Suddaby, R., and Greenwood, R. (2005). Rhetorical strategies of legitimacy. Administrative science quarterly, 50(1), pp. 35-67.

Steverson, B. K. (2012). Vulnerable values argument for the professionalization of business management. Business and Professional Ethics Journal, 31(1), 51-77.

Swann, M., McIntyre, D., Pell, T., Hargreaves, L., \& Cunningham, M. (2010). Teachers' conceptions of teacher professionalism in England in 2003 and 2006. British educational research journal, 36(4), pp. 549-571.

Tait, M. (2012). Building trust in planning professionals: understanding the contested legitimacy of a planning decision. Town Planning Review, 83(5), pp. 597-619.

Taylor, I., and Bogo, M. (2014). Perfect opportunity perfect storm? Raising the standards of social work education in England. British Journal of Social Work, 44(6), pp. 1402-1418.

Taylor, M., and Yang, A. (2015). Have global ethical values emerged in the public relations industry? Evidence from national and international professional public relations associations. Journal of business ethics, 130(3), pp. 543-555.

Teodoro, M. P. (2009). Bureaucratic job mobility and the diffusion of innovations. American Journal of Political Science, 53(1), pp. 175-189.

Teodoro, M. P., and Hughes, A. G. (2012). Socializer or signal? how agency accreditation affects organizational culture. Public Administration Review, 72(4), pp. 583-591

Terry, K. S. (2009). Externships: A signature pedagogy for the apprenticeship of professional identity and purpose. Journal of Legal Education, 59(2), pp. 240-268.

Thursfield, D. (2012). The social construction of professionalism among organizers and senior organizers in a UK trade union. Work, employment, and society, 26(1), pp. 128-144.

Turner, A. H. (2015). Instilling public service values and professionalism through information literacy. Journal of Public Affairs Education, 21(1), pp. 41-54.

Urban, M., Vandenbroeck, M., Van Laere, K., Lazzari, A., and Peeters, J. (2012). Towards competent systems in early childhood education and care. Implications for policy and practice. European Journal of Education, 47(4), pp. 508526

Vaidyanathan, B. (2012). Professionalism 'from below': mobilization potential in Indian call centres. Work, employment, and society, 26(2), pp. 211-227.

Vamstad, J. (2012). Co-production and service quality: The case of cooperative childcare in Sweden. VOLUNTAS: International Journal of Voluntary and Nonprofit Organizations, 23(4), pp. 1173-1188.

Van Der Wal, Z., Huberts, L., Van den Heuvel, H., and Kolthoff, E. (2006). Central values of government and business: Differences, similarities, and conflicts. Public Administration Quarterly, 30(3/4), pp. 314-364.

Van Hise, J., and Massey, D. W. (2010). Applying the Ignatian pedagogical paradigm to the creation of an accounting ethics course. Journal of Business Ethics, 96(3), pp. 453-465.

Van Laere, K., Peeters, J., and Vandenbroeck, M. (2012). The education and care divide: The role of the early childhood workforce in 15 European countries. European Journal of Education, 47(4), pp. 527-541.

Veasey, E. N., and Di Guglielmo, C. T. (2006). The Tensions, Stresses, and Professional Responsibilities of the Lawyer for the Corporation. The Business Lawyer, 62(1), 1-36.

Vivant, E. (2016). Rejection, adoption or conversion: the three ways of being a young graduate autoentrepreneur. Work Organisation, Labour and Globalisation, 10(2), 68-83.

Wald, E. (2007). The rise and fall of the WASP and Jewish law firms. Stan. L. Rev., 60, pp. 1803-1866.

Wallace, J. E., and Kay, F. M. (2008). The professionalism of practising law: A comparison across work contexts. Journal of Organizational Behavior: The International Journal of Industrial, Occupational and Organizational Psychology and Behavior, 29(8), pp. 1021-1047. 
Walton, R. (2005). Social work as a social institution. British Journal of Social Work, 35(5), pp. 587-607.

Watts, D. (2014). Address by the President of the Institute and Faculty of Actuaries Dr David Hare. British Actuarial Journal, 19(2), pp. 259-272.

Westerlund, H. M. (2020). Stories and Narratives as Agencies of Change in Music Education: Narrative Mania or a Resource for Developing Transformative Music Education Professionalism? Bulletin of the Council for Research in Music Education, (223), pp. 7-25.

Whitty, G., and Wisby, E. (2006). Moving beyond recent education reform-and towards a democratic professionalism. Hitotsubashi journal of social studies, 38(1), pp. 43-61.

Williams, K. (2008). Troubling the concept of the 'academic profession' in 21st Century higher education. Higher Education, 56(5), 533-544.

Wilson-Kovacs, D. (2014). 'Backroom boys': occupational dynamics in crime scene examination. Sociology, 48(4), 763779.

Wukich, C. (2014). Professional capital: Standards of performance that underlie interlocal cooperation. Public Administration Quarterly, 38(4), pp. 573-604

Yaqing, L. (2011). The Power of Archives: Archivists' Values and Value in the PosBRodern Age. Archives Science Study, 20(2), pp. 17-41

Yi-chong, X., and Weller, P. (2009). Chrik PoorBRan: A World Bank Professional. Public administration review, 69(5), pp. 868-875.

Zaloznaya, M., and Nielsen, L. B. (2011). Mechanisms and Consequences of Professional Marginality: The Case of Poverty Lawyers Revisited. Law \& Social Inquiry, 36(4), pp. 919-944.

Zhang, Y., and Feiock, R. C. (2010). City managers' policy leadership in council-manager cities. Journal of Public Administration Research and Theory, 20(2), pp. 461-476. 